\title{
Pharmacological Characterization of Low-to-Moderate Affinity Opioid Receptor Agonists and Brain Imaging with ${ }^{18} \mathrm{~F}$-Labeled Derivatives in Rats
}

\author{
Julian Ott, Mona M. Spilhaug, Simone Maschauer, Waqas Rafique, Jimmy E. Jakobsson, Karoline Hartvig, \\ Harald Hübner, Peter Gmeiner, Olaf Prante, and Patrick J. Riss*
}

Cite This: J. Med. Chem. 2020, 63, 9484-9499

Read Online

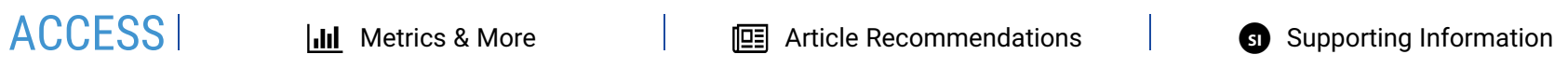

ABSTRACT: The 3,4-dichloro- $N$-(1-(dimethylamino)cyclohexyl)methyl benzamide scaffold was studied as a template for ${ }^{18} \mathrm{~F}$-positron emission tomography $\left({ }^{18} \mathrm{~F}-\mathrm{PET}\right)$ radiotracer development emphasizing sensitivity to changes in opioid receptor (OR) occupancy over high affinity. Agonist potency, binding affinity, and relevant pharmacological parameters of 15 candidates were investigated. Two promising compounds $3 \mathbf{b}$ and $3 \mathbf{e}$ with $\mu$-OR (MOR) selective agonist activity in the moderate range $\left(\mathrm{EC}_{50}=1-100 \mathrm{nM}\right)$ were subjected to ${ }^{18} \mathrm{~F}$ fluorination, autoradiography, and small-animal PET imaging. Radioligands $\left[{ }^{18} \mathrm{~F}\right] 3 \mathbf{b}$ and $\left[{ }^{18} \mathrm{~F}\right] 3 \mathbf{e}$ were obtained in activity yields of $21 \pm 5$ and $23 \pm 4 \%$ and molar activities of $25-40$ and $200-300 \mathrm{GBq} / \mu \mathrm{mol}$,

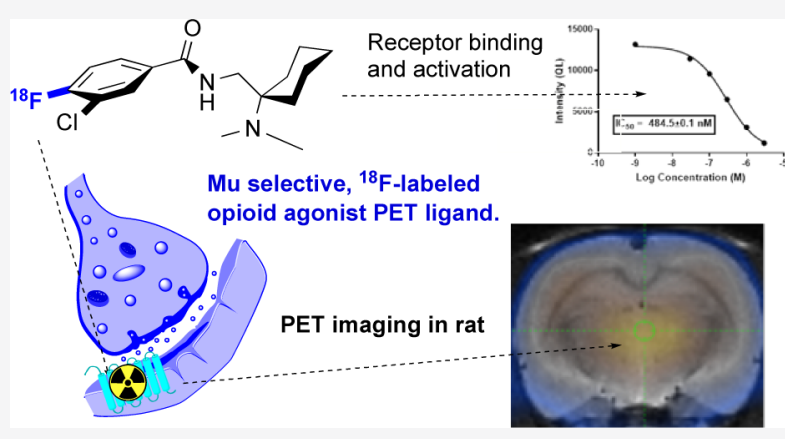
respectively. Displaceable binding matching MOR distribution in the brain was confirmed by imaging. Radioligands showed a rapid pharmacokinetic profile; however, metabolite-corrected, blood-based modeling was required for data analysis. Observed $\mathrm{BP}_{\mathrm{ND}}$ was low, although treatment with naloxone leads to a marked decrease in specific binding, confirming the discovery of a new template for ${ }^{18}$ F-labeled OR-agonist PET ligands.

\section{INTRODUCTION}

Opioid receptors (ORs) are G-protein-coupled receptors (GPCR) of some prominence in quantitative imaging studies. Because opioid signaling is implicated in a variety of central precipitations of behavior and disease, the study of ORs, specifically, $\mu$ (MOR), $\delta$ (DOR), and $\kappa$ (KOR), is of interest in the scientific context of decision making, addiction, and pain processing. ${ }^{1,2}$ These subtypes share a common amino acid sequence but vary widely in both their endogeneous and exogeneous ligands and their individual physiological functions. Although OR binding sites are expressed throughout the human brain, few regions show a distinct predominance of a single subtype. The highest fractions of expression of any subtype are found in the substantia nigra $(66 \% \mathrm{KOR})$ and the thalamus (67\% MOR), reflecting the need for a subtype-selective radioligand with sufficient binding selectivity in vivo when attempting to study the function and role of a single OR in the brain. ${ }^{1-7}$ In recent years, a new interest in OR radioligands developed, for example, because of an opioid abuse crisis. The limited availability, toxicity, and short half-life of $\left[{ }^{11} \mathrm{C}\right]$ carfentanil, which is the only MOR-selective positron emission tomography (PET) ligand in use, prompted us to explore an alternative path. $^{5-8}$ Our approach was motivated by ongoing discussions on the mechanism of displacement of the PET ligand from the OR receptor by endogeneous ligands and drug molecules. ${ }^{7-9}$
In fact, imaging OR occupancy by various agonist ligands has been difficult, and it is generally accepted that antagonists are not fit for the purpose. Although these have the principal advantage of being less prone to cause undesired pharmacodynamic effects and toxicity, antagonists bind to both activated (Gprotein bound) and nonactivated (unbound) receptors, which leads to a very limited sensitivity in changes to the activated receptor population. Agonist binding, in particular, $\left[{ }^{11} \mathrm{C}\right]$ carfentanil binding, in PET studies has been found to be considerably more sensitive to changes in OR availability. ${ }^{5-9}$

However, high binding affinity of $\left[{ }^{11} \mathrm{C}\right]$ carfentanil $(0.03-0.08$ $\mathrm{nM}$ ) results in a high binding potential which has been shown to reflect cell surface receptor expression, not competition with other agonists. ${ }^{9}$ Moreover, the ligand is potent enough to induce pharmacodynamic effects at the dose level of PET, leading to a change in receptor density by internalization. OR receptor internalization upon stimulation by endogeneous agonists reduces $\left[{ }^{11} \mathrm{C}\right]$ carfentanil binding; however, internalization is

Received: April 24, 2020

Published: July 31, 2020 


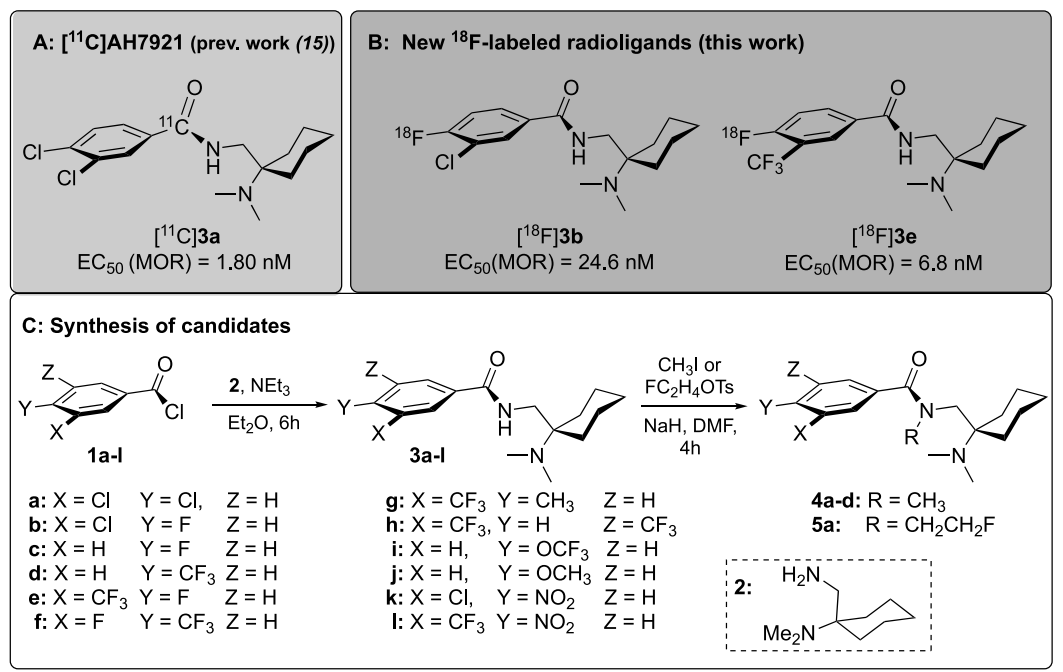

Figure 1. Chemical structure of the ${ }^{11} \mathrm{C}$-labeled analogue of lead $3 \mathbf{a}^{8}(\mathrm{~A})$ and newly developed ${ }^{18} \mathrm{~F}$-labeled candidate PET ligands $\left[{ }^{18} \mathrm{~F}\right] 3 \mathbf{b}$ and $\left[{ }^{18} \mathrm{~F}\right] \mathbf{3 e}$ (B) and the general course of the syntheses of the compounds under study starting from the primary amine [1-(N,N-dimethylamino)-cyclohex-1yl]methylamine (2) and various substituted benzoyl chlorides 1a-l to get the nonradioactive fluoro-substituted reference compounds and the nitro precursors (C).

not induced by all agonists. For example, morphine and oxycodone do not cause internalization, whereas fentanyl, DAMGO, and endogeneous opioids do, although all of these are full agonists. $^{9-12}$ The dose limit for the highly potent $\left[{ }^{11} \mathrm{C}\right]$ carfentanil is $0.1 \mu \mathrm{g} / \mathrm{kg}$, and even at such a low dose, patients may experience pharmacodynamic effects of OR activation. ${ }^{6,9-13}$ This is not ideal when considering PET as a noninvasive method and problematic when combined with the implications of quantifying receptor availability with a ligand that has an effect on the system to be observed at the administered dose. In addition, the most striking issue in the context is that imaging OR occupancy in subjects under the influence of OR agonists with such a potent ligand is prohibitive because of an additional pharmacodynamic effect leading to overactivation, acute toxicity, respiratory depression, and possibly death..$^{5-10}$ Although radiolabeled low-to-moderate affinity OR agonists with moderate potency would not suffer from the toxicity and lack sensitivity to displacement, such ligands have never been fully characterized for PET. High affinity necessitates extensive imaging sessions $(3-4 \mathrm{~h})^{6}$ but is assumed to be crucial for OR agonist PET; however, this has never been proven.

Last but not least, the lack of subtype selectivity as an inherent property of semisynthetic opioid ligands sourced from the morphinan or orvinol scaffolds. PET ligands derived from these scaffolds retain the lack of discrimination between different OR subtypes showing near identical affinities in all receptors, thereby confounding studies of single-receptor subtypes in normal function and disease. ${ }^{14,15}$

Inspired by a revised radioligand design paradigm emphasizing the competition model for signal displacement and occupancy measurements, more rapid equilibration of binding, and fast clearance, ${ }^{7,8,15}$ we have turned our attention to moderate-affinity, low-molecular-weight opioid agonists. The benzamide AH-7921, 3,4-dichloro- $N$-(1-(dimethylamino)cyclohexyl)benzamide, 3a was successfully investigated previously. Herein, the structure is utilized as a template for the development of fluorinated analogues. ${ }^{8,15}$

(Figure 1) The aim of the present study is to provide an alternative OR agonist PET ligand, which permits straightfor- ward quantification of MOR availability in rodents within 60 min postinjection (p.i.) and facilitates occupancy measurements in patients under the influence of therapeutic opioid agonist doses.

The radioligand $\left[{ }^{11} \mathrm{C}\right] 3 \mathrm{a}$ (Figure $1 \mathrm{~A}$ ) showed a promising performance in rodent PET studies; ${ }^{8}$ however, an ${ }^{18} \mathrm{~F}$-labeled derivative fulfilling the above-mentioned criteria, including fast pharmacokinetics and kinetics and high in vivo selectivity in favor of the MOR, together with the benefit of a longer half-life would add value to the portfolio of already existing opioid ligands for PET.

\section{RESULTS AND DISCUSSION}

Chemistry. In previous studies, we demonstrated that the radioligand $\left[{ }^{11} \mathrm{C}\right] 3$ a showed a promising performance in rodent PET studies. ${ }^{15}$ However, given the low yield and short half-life of $\left[{ }^{11} \mathrm{C}\right] 3 \mathrm{a}$, an ${ }^{18} \mathrm{~F}$-labeled radioligand would be more desirable. Although the parent structure $3 a$ does not contain any native fluorine atoms, we chose it as a design template for novel OR ligands within a molecular weight range of $280-380 \mathrm{~g} / \mathrm{mol}$. Emphasis was put on permeative properties within the required thresholds for passive diffusion into the brain. ${ }^{16} \mathrm{~A}$ concise synthetic strategy was exploited to furnish ${ }^{18} \mathrm{~F}$-fluorinated analogues backed with an intrinsic selectivity profile of the scaffold in favor of the MOR. Fifteen analogues $(3 a-j, 4 a-d$, and 5a) were designed by introduction of fluorine at the phenyl moiety of the benzamide in para and/or meta position. The para position is activated for nucleophilic aromatic substitution with $\left.{ }^{18} \mathrm{~F}\right]$ fluoride which bodes well for ${ }^{18} \mathrm{~F}$-for- $-\mathrm{NO}_{2}$ substitution starting from nitro precursors $3 \mathrm{k}$ or 31 . Besides the introduction of fluorine in para position, the chloro substituent was retained in meta position of the lead compound in $\mathbf{3 b}$ and substituted with the isosteric trifluoromethyl group in compound $3 \mathbf{e}$ (Figure 1B). The series of ligands was obtained in one step via Schotten-Baumann condensation of the commercially available benzoyl chlorides 1a-1 with [1-( N,N-dimethylamino)-cyclohex1-yl] methylamine (2), obtained as described previously (Figure 1C). ${ }^{15}$ Besides the introduction of sites for ${ }^{18} \mathrm{~F}$-radiolabeling, we aimed to maintain the lipophilicity $\left(\log D_{7.4}\right)$ and topographical polar surface area (tPSA) of the compounds under study within 
Table 1. Receptor Binding Affinities of Compounds $3 a-j$ and $4 a-d^{a}$

\begin{tabular}{|c|c|c|c|c|c|c|c|}
\hline \multirow[t]{2}{*}{ Cmpd. } & \multicolumn{4}{|c|}{ Substituents } & \multicolumn{3}{|c|}{$\mathrm{K}_{\mathrm{i}}$ values $(\mathrm{nM} \pm \mathrm{SD})^{b}$} \\
\hline & $\mathrm{X}$ & $\mathrm{Y}$ & Z & $\mathrm{R}$ & hDOR & hKOR & hMOR \\
\hline $\mathbf{3 a}^{c}$ & $\mathrm{Cl}$ & $\mathrm{Cl}$ & $\mathrm{H}$ & $\mathrm{H}$ & $750 \pm 490$ & $260 \pm 50$ & $110 \pm 30$ \\
\hline $4 a$ & $\mathrm{Cl}$ & $\mathrm{Cl}$ & $\mathrm{H}$ & $\mathrm{CH}_{3}$ & $4500 \pm 990$ & $1100 \pm 440$ & $370 \pm 130$ \\
\hline $3 \mathbf{b}$ & $\mathrm{Cl}$ & $\mathrm{F}$ & $\mathrm{H}$ & $\mathrm{H}$ & $3900 \pm 210$ & $910 \pm 550$ & $560 \pm 50$ \\
\hline $4 b$ & $\mathrm{Cl}$ & $\mathrm{F}$ & $\mathrm{H}$ & $\mathrm{CH}_{3}$ & $31000 \pm 9900$ & $6200 \pm 990$ & $3000 \pm 570$ \\
\hline $3 \mathrm{c}$ & $\mathrm{H}$ & $\mathrm{F}$ & $\mathrm{H}$ & $\mathrm{H}$ & $20000 \pm 4200$ & $3500 \pm 350$ & $2300 \pm 710$ \\
\hline $4 c$ & $\mathrm{H}$ & $\mathrm{F}$ & $\mathrm{H}$ & $\mathrm{CH}_{3}$ & $82000 \pm 8500$ & $21000 \pm 710$ & $32000 \pm 5700$ \\
\hline $3 d$ & $\mathrm{H}$ & $\mathrm{CF}_{3}$ & $\mathrm{H}$ & $\mathrm{H}$ & $1700 \pm 320^{d}$ & $830 \pm 140^{d}$ & $130 \pm 32^{d}$ \\
\hline $4 d$ & $\mathrm{H}$ & $\mathrm{CF}_{3}$ & $\mathrm{H}$ & $\mathrm{CH}_{3}$ & $7600 \pm 1100$ & $4400 \pm 0$ & $1400 \pm 570$ \\
\hline $3 e$ & $\mathrm{CF}_{3}$ & $\mathrm{~F}$ & $\mathrm{H}$ & $\mathrm{H}$ & $2000 \pm 320^{d}$ & $190 \pm 45^{d}$ & $160 \pm 33^{d}$ \\
\hline $3 f$ & $\mathrm{~F}$ & $\mathrm{CF}_{3}$ & $\mathrm{H}$ & $\mathrm{H}$ & $370 \pm 100^{d}$ & $220 \pm 5.8^{d}$ & $25 \pm 6.6^{d}$ \\
\hline $3 g$ & $\mathrm{CF}_{3}$ & $\mathrm{CH}_{3}$ & $\mathrm{H}$ & $\mathrm{H}$ & $1400 \pm 210^{d}$ & $110 \pm 26^{d}$ & $45 \pm 6.8^{d}$ \\
\hline $3 \mathbf{h}$ & $\mathrm{CF}_{3}$ & $\mathrm{H}$ & $\mathrm{CF}_{3}$ & $\mathrm{H}$ & $3400 \pm 780^{d}$ & $420 \pm 140^{d}$ & $240 \pm 74^{d}$ \\
\hline $3 \mathbf{i}$ & $\mathrm{H}$ & $\mathrm{OCF}_{3}$ & $\mathrm{H}$ & $\mathrm{H}$ & $4600 \pm 600$ & $2500 \pm 950$ & $460 \pm 130$ \\
\hline $3 \mathbf{j}$ & $\mathrm{H}$ & $\mathrm{OCH}_{3}$ & $\mathrm{H}$ & $\mathrm{H}$ & $9700 \pm 300$ & $3600 \pm 1400$ & $1000 \pm 70$ \\
\hline
\end{tabular}

${ }^{a}$ Receptor binding affinities derived from radioligand competition binding experiments performed in triplicate using membranes of HEK 293T cells transiently expressing the human OR subtypes. ${ }^{b} K_{\mathrm{i}}$ values represent the mean of two independent experiments $\pm \mathrm{SD}$, each performed in triplicate. ${ }^{c} K_{\mathrm{i}}$ values \pm SEM taken from ref $18 .{ }^{d} K_{\mathrm{i}}$ values represent the mean of three to four independent experiments \pm SEM, each performed in triplicate.

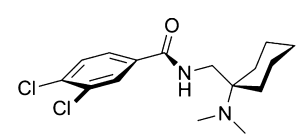

3a

$\mathrm{EC}_{50}(\mathrm{MOR})=1.8 \mathrm{nM}$ $E C_{50}(K O R)=229.3 \mathrm{nM}$ $\mathrm{EC}_{50}(\mathrm{DOR})=63.7 \mathrm{nM}$ tPSA $=32.3 ; V_{m}=267.4$ $\operatorname{clog} P=3.7 ; \log D_{7.4}=3.5$

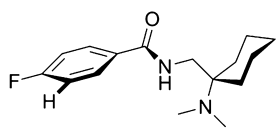

$3 c$
$\mathrm{EC}_{50}(\mathrm{MOR})=179.1 \mathrm{nM}$ $\mathrm{EC}_{50}(\mathrm{KOR})=6154 \mathrm{nM}$ $\mathrm{EC}_{50}(\mathrm{DOR})=6803 \mathrm{nM}$ $\operatorname{tPSA}=23.6 ; \mathrm{V}_{\mathrm{m}}=262.3$ $\operatorname{clog} P=3.3 ; \log D_{7.4}=2.9$<smiles>CN(C)C1(CNC(=O)c2ccc(C(F)(F)F)c(F)c2)CCCC1</smiles>
$3 \mathbf{f}$

$\begin{aligned} & \mathbf{3 f} \\ & \mathrm{EC}_{50}(\mathrm{MOR})\end{aligned}=1.2 \mathrm{nM}$ $\begin{aligned} \mathrm{EC}_{50}(\mathrm{MOR}) & =1.2 \mathrm{nM} \\ \mathrm{EC}_{50}(\mathrm{KOR}) & =115.4 \mathrm{nM}\end{aligned}$ $\mathrm{EC}_{50}(\mathrm{DOR})=27.1 \mathrm{nM}$ $\begin{aligned} \text { tPSA } & =32.3 ; V_{m}=269.5 \\ \operatorname{cog} P & =4.1 ; \log D_{7.4}=3.9\end{aligned}$

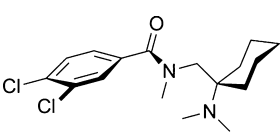

$4 a$ 4a
$\mathrm{EC}_{50}(\mathrm{MOR})=11.0 \mathrm{nM}$
$\mathrm{EC}_{50}(\mathrm{KOR})=664.3 \mathrm{nM}$ $\mathrm{EC}_{50}(\mathrm{DOR})=2268 \mathrm{nM}$ tPSA $=23.6 ; V_{m}=287.4$ $\operatorname{clog} P=4.0 ; \log D_{7.4}=3.5$

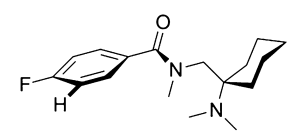

$4 c$

$\mathrm{EC}_{50}(\mathrm{MOR})=6716 \mathrm{nM}$ $\mathrm{EC}_{50}(\mathrm{KOR})=5477 \mathrm{nM}$ $\mathrm{EC}_{50}(\mathrm{DOR})=5477 \mathrm{nM}$ tPSA $=23.6 ; V_{\mathrm{m}}=262.3$ $\operatorname{clog} P=3.3 ; \log D_{7.4}=3.1$

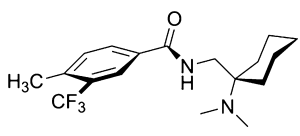

$\mathrm{EC}_{50}(\mathrm{MOR})=1.0 \mathrm{nM}$ $\mathrm{EC}_{50}(\mathrm{KOR})=46.4 \mathrm{nM}$ $\mathrm{EC}_{50}(\mathrm{DOR})=87.9 \mathrm{nM}$ $\begin{aligned} \mathrm{tPSA} & =32.3 ; \mathrm{V}_{\mathrm{m}}=269.8 \\ \operatorname{cog} \mathrm{P} & =5.8 ; \log \mathrm{D}_{7.4}=4.1\end{aligned}$
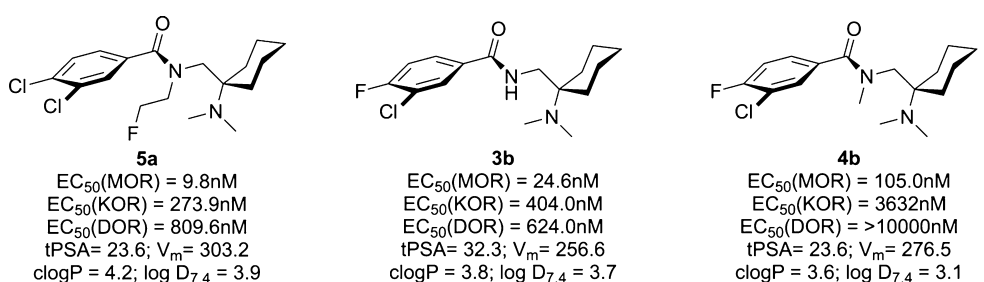

4b

$\mathrm{EC}_{50}(\mathrm{MOR})=105.0 \mathrm{nM}$ $\mathrm{EC}_{50}(\mathrm{KOR})=3632 \mathrm{nM}$ $\mathrm{EC}_{50}(\mathrm{DOR})=>10000 \mathrm{nM}$ tPSA $=23.6 ; V_{m}=276.5$ $\operatorname{cog} \mathrm{P}=3.6 ; \log \mathrm{D}_{7.4}=3.1$
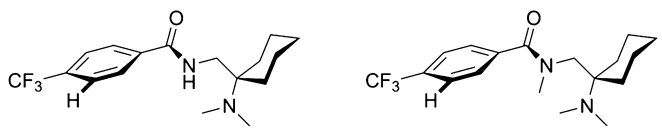

4d

$$
\begin{gathered}
4 d \\
E C_{50}(M O R)=39.9 n M \\
E C_{50}(K O R)=2333 n M \\
E C_{50}(D O R)=2241 n M \\
t P S A=23.6 ; V_{m}=286.3
\end{gathered}
$$
$\operatorname{clog} P=3.8 ; \log D_{7.4}=2.8$

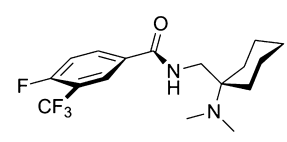

$\mathrm{EC}_{50}(\mathrm{MOR})=4.9 \mathrm{nM}$ $\mathrm{EC}_{50}(\mathrm{KOR})=997.9 \mathrm{nM}$ $E C_{50}(\mathrm{DOR})=154.3 \mathrm{nM}$ $\begin{aligned} \operatorname{tPSA} & =32.3 ; \mathrm{V}_{\mathrm{m}}=266.3 \\ \operatorname{clog} \mathrm{P} & =4.0 ; \log \mathrm{D}_{7.4}=3.6\end{aligned}$
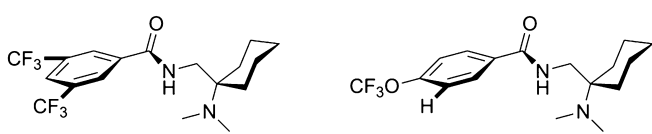

$3 \mathrm{~h}$

$\mathrm{EC}_{50}(\mathrm{MOR})=7.5 \mathrm{nM}$ $E C_{50}(K O R)=1622 \mathrm{nM}$ $\mathrm{CC}_{50}(\mathrm{DOR})=466.4 \mathrm{nM}$ $\begin{aligned} \text { tPSA } & =32.3 ; V_{m}=296.1 \\ \operatorname{cog} P & =4.5 ; \log D_{7.4}=3.6\end{aligned}$
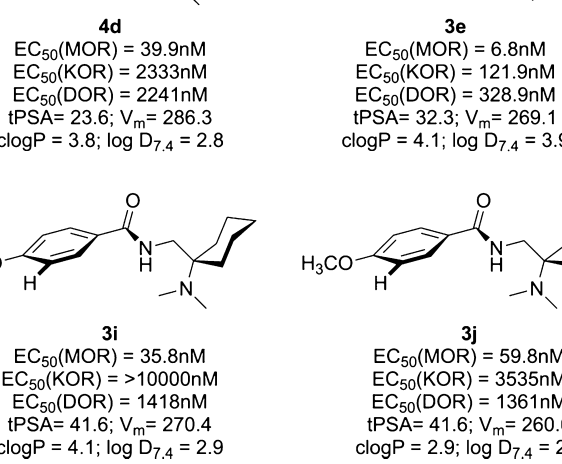

$\mathrm{EC}_{50}(\mathrm{MOR})=6.8 \mathrm{nM}$ $\mathrm{EC}_{50}(\mathrm{KOR})=121.9 \mathrm{nM}$ $\mathrm{EC}_{50}(\mathrm{DOR})=328.9 \mathrm{nM}$ $\begin{aligned} \operatorname{tPSA} & =32.3 ; \mathrm{V}_{\mathrm{m}}=269.1 \\ \operatorname{cog} \mathrm{P} & =4.1 ; \log \mathrm{D}_{7.4}=3.9\end{aligned}$

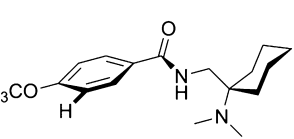

$\mathbf{3 j}$
$\mathrm{EC}_{50}(\mathrm{MOR})=59.8 \mathrm{nM}$ $E C_{50}(K O R)=3535 \mathrm{nM}$ $\mathrm{EC}_{50}(\mathrm{DOR})=1361 \mathrm{nM}$ $\begin{aligned} \mathrm{tPSA} & =41.6 ; V_{m}=260.6 \\ \operatorname{cog} P & =2.9 ; \log D_{7.4}=2.7\end{aligned}$

Figure 2. Chemical structure, agonist potency at hDOR, hKOR, and hMOR receptors, tPSA, and octanol/water partition coefficients (clog $P$ and tPSA values were calculated with ChemBioDraw 13.0 and $\log D_{7.4}$ values were experimentally determined for all candidate ligands under study). DAMGO $\left(\mathrm{MOR}, \mathrm{EC}_{50}=0.91 \mathrm{nM}\right),[\mathrm{D}-\mathrm{Ala} 2]$-deltorphine $\left(\mathrm{DOR}, \mathrm{EC}_{50}=0.25 \mathrm{nM}\right)$, and U50,488 $\left(\mathrm{KOR}, \mathrm{EC}_{50}=3.2 \mathrm{nM}\right)$ were included as references.

the range of established brain imaging agents and below the thresholds associated with adverse effects on brain uptake. ${ }^{16,17}$ To simplify the task, threshold values were defined using data from an array of 12 compounds, six opioids and six nonopioid PET radiotracers. We found that $\log P$ values vary between 3 and 4 for a large proportion of the radioligands and that tPSA barely exceeded a value of $60 \AA$. Consequently, these values were set as upper thresholds for the present study. With these criteria in mind, we designed a set of ligands to explore modifications in the chemical space in close proximity to the lead $3 a .{ }^{18}$ This narrow frame without major deviations from both weight and structure was used to emphasize effects of fluorination in a structureactivity relationship focused on agonist potency and binding affinity. New derivatives $(\mathbf{3 a}-\mathbf{1}, \mathbf{4 a}-\mathbf{d}$, and $\mathbf{5 a})$ were obtained in yields of $56-79 \%$ with a purity of $>97 \%$ and tested for receptor binding, agonist activity, and basic pharmacological properties. The results are shown in Table 1 and Figure 2. 
Receptor Binding Studies and Determination of Agonist Potency. The receptor binding affinities of synthesized compounds toward the DOR, KOR, and MOR subtypes were studied using transiently transfected human embryonic kidney (HEK) 293T cells using $\left[{ }^{3} \mathrm{H}\right]$ diprenorphine as the radioligand (Table 1), following the procedure as described previously. ${ }^{18,20}$ DAMGO [MOR, $K_{\mathrm{i}}=25 \pm 4.4 \mathrm{nM}(n=9)$; DOR, $K_{\mathrm{i}}=1000 \pm 150 \mathrm{nM}(n=6) ; \mathrm{KOR}, K_{\mathrm{i}}=4200 \pm 1200 \mathrm{nM}$ $(n=6))$, Leu-Enk (MOR, $K_{\mathrm{i}}=160 \pm 30 \mathrm{nM}(n=9) ; \mathrm{DOR}, K_{\mathrm{i}}=$ $\left.6.8 \pm 0.58 \mathrm{nM}(n=6) ; \mathrm{KOR}, K_{\mathrm{i}}=15,000 \pm 1200 \mathrm{nM}(n=6)\right]$ and naloxone $\left[\mathrm{MOR}, K_{\mathrm{i}}=3.3 \pm 0.33 \mathrm{nM}(n=18) ; \mathrm{DOR}, K_{\mathrm{i}}=56\right.$ $\pm 4.6 \mathrm{nM}(n=18)$; KOR, $\left.K_{\mathrm{i}}=16 \pm 3.9 \mathrm{nM}(n=10)\right]$ were included as references. The potency of the compounds was determined in Chinese hamster ovary ( $\mathrm{CHO}$ ) cells stably transfected with the DOR, KOR, and MOR by measuring the agonist-mediated inhibition of intracellular cAMP response (Figure 2), using references deltorphin (DOR), U50488 (KOR), and DAMGO (MOR).

Regarding structural aspects, the OR binding affinity and the agonist activity of the compounds were sensitive to both substitutions on the benzoyl residue (at positions $X$ and $Y$ ) and methylation of the benzamide nitrogen. In general, a large substituent, such as chlorine, or its isostere trifluoromethyl in para position of the phenyl ring is crucial to retain the MOR binding affinity, as can be seen by comparison of $\mathbf{3 a}$ with $\mathbf{3 b}$ and $3 \mathbf{c}$ with $3 \mathbf{d}$, and $\mathrm{N}$-methylation clearly reduced the binding affinity by a factor of 5 or more $(4 \mathbf{a}-\mathbf{d}$ and $5 \mathbf{a}$; Table 1 and Figure 2). Compared to the lead compound 3a, fluoro-forchloro substitution in $\mathbf{3 b}$ reduced the affinity for the MOR by a factor of 5 (Table 1) and the potency for the MOR by a factor of 14 (Figure 2). This trend continues when both chloro substituents were displaced by lighter elements, such as $\mathrm{H}$ or $\mathrm{F}$, as in the case of $3 \mathbf{c}$ (Table 1 and Figure 2). Apparently, a sizeable, nonpolar substituent, such as $\mathrm{Cl}, \mathrm{CF}_{3}$, or $\mathrm{CH}_{3}$, in para position of the benzoyl moiety is required to maintain maximum agonist potency for the MOR. With the trifluoromethyl group in para position (3d), even without the meta-chloro substituent, MOR affinity and potency were similar to those of lead $3 a$. Interestingly, the introduction of a meta-fluoro substituent (see 3f) further increased the receptor binding affinities (Table 1) and efficacies (Figure 2); however, a pronounced DOR activation and only low MOR-over-DOR selectivity were observed for $\mathbf{3 f}$.

When introducing the $\mathrm{CF}_{3}$ group in meta position ( $X$ in Figure 1) of the benzene ring in lieu of a chloride, the receptor binding affinity to the MOR (Table 1) and the efficacy (Figure 2 ) were no longer strongly influenced by the substituent in para position ( $Y$ in Figure 1 ) such that fluoro (3e), hydrogen (3h), and methyl (3g) were equally tolerated by the MOR, resulting in affinities $\left(K_{\mathrm{i}}=25-240 \mathrm{nM}\right)$ and potencies $\left(\mathrm{EC}_{50}=1-8 \mathrm{nM}\right)$ that were very similar to those of the lead $3 a$ (Table 1, Figure 2). In comparison with the lead $\mathbf{3 a}$, a pronounced decrease in affinity to all receptors was observed when the para-chloro substituent was replaced by electron-donating groups such as $\mathrm{OCF}_{3}$ or $\mathrm{OCH}_{3}$ as in compounds $3 \mathbf{i}$ and $3 \mathbf{j}$, demonstrating the involvement of electronic effects. To sum up, substitution of $\mathrm{Cl}$ for $\mathrm{F}$ or $\mathrm{CF}_{3}$-isosteres retained the binding affinity and potency, while electron-donating or less-electronegative substituents had a negative influence on potency and subtype selectivity.

Noteworthy, the $K_{\mathrm{i}}$ values obtained by receptor binding experiments using the antagonist radioligand $\left[{ }^{3} \mathrm{H}\right]$ diprenorphine were in the three-digit nanomolar range owing to a bias of the assay also seen for agonist references. This apparently low binding affinity was ascribed to the fact that the tested agonists have high binding affinity to the activated receptor conformation and low affinity to the nonactivated receptor state, whereas the antagonist radioligand $\left[{ }^{3} \mathrm{H}\right]$ diprenorphine binds with equal affinity to both high- and lowaffinity binding states of the receptor. The MOR-transfected HEK cells did not express the G-protein-coupled, active receptor, which binds the agonist ligand, in sufficient density, for example, because of the medium employed. ${ }^{8-11,21}$ Because of the excess nonactivated receptor state, the agonist test compounds do not show a major displacement of the antagonist radioligand at low concentration. At high concentration, the test compound effect can be ascribed to low affinity binding to the nonactivated receptor state, as expected for OR agonists. Using the same HEK cells, but $\left[{ }^{18} \mathrm{~F}\right] 3 \mathbf{b}(0.4 \mathrm{nM})$ instead of $\left[{ }^{3} \mathrm{H}\right]$ diprenorphine as the radioligand, we observed $32 \%$ diminished binding in the presence of naloxone $(0.4 \mathrm{nM})$ and $33 \%$ diminished binding in the presence of $3 \mathrm{k}(1 \mu \mathrm{M})$; however, the determination of $K_{\mathrm{d}} / B_{\max }$ was not possible, apparently because of the low concentration of represented receptors with an activated receptor state. It is a well-known phenomenon that OR antagonist binding is not very sensitive to agonist competition; however, agonist binding is exceptionally sensitive to antagonist displacement even for high-affinity agonist ligands. ${ }^{5-8,15,22}$ Ultimately, we can only conclude that the ligands have a lower affinity to the nonactivated state which leads to displacement of the majority of the antagonist radioligands at high concentration.

Within the series of compounds, the para position appears to be more relevant for MOR activity, whereas the 3-chloro substituent positively influences DOR and KOR activation and, thereby, selectivity. This trend is persistent throughout the series. Despite the structural modification, almost all ligands retain selective agonism for the MOR over the KOR and DOR with nanomolar potency (Figure 2). Interestingly, alkylation leads to a drop in binding affinity and agonist activity of about 1 order of magnitude at the MOR, which negatively impacts the selectivity over the other subtypes in most cases. The two parafluoro derivatives $\mathbf{3 b}$ and $\mathbf{3 e}$, with chloro- and trifluoromethyl substituents in meta position, respectively, resulted in an increased affinity and potency when compared to the nonsubstituted derivatives and display the desired moderate binding affinity for the MOR with a $K_{\mathrm{i}}$ value of $560 \mathrm{nM}$ for $3 \mathrm{~b}$ and 160 $\mathrm{nM}$ for $3 \mathbf{e}$ (Table 1). Because the compounds show a moderate potency for the MOR with a single-to-two-digit nanomolar $\mathrm{EC}_{50}$ value together with an adequate subtype selectivity (Figure 2) and easy accessibility of the corresponding para-nitro precursors ( $3 \mathbf{k}$ and $3 \mathbf{l}$ ), $3 \mathbf{b}$ and $3 \mathrm{e}$ were selected from the series for ${ }^{18} \mathrm{~F}$ labeling and further in vitro and in vivo studies were carried out.

In Vitro Autoradiography. Before proceeding toward the radiosynthesis and in vivo evaluation of $\left[{ }^{18} \mathrm{~F}\right] 3 \mathbf{b}$ and $\left[{ }^{18} \mathrm{~F}\right] \mathbf{3 e}$ in animals, we aimed at testing the MOR selectivity and the binding affinity of both compounds using rat brain tissue sections. For this, in vitro autoradiography (AR) experiments were performed, and concentration-dependent inhibition of binding of both $3 \mathbf{b}$ and $3 \mathbf{e}$ against $\left[{ }^{3} \mathrm{H}\right]$ DAMGO, an MORselective agonist, and $\left[{ }^{3} \mathrm{H}\right]$ naloxone as an antagonist radioligand was determined. Transverse sections of Sprague-Dawley rat brain were incubated at nine different concentrations of $\mathbf{3 b}$ and 3e using constant amounts of both the radioligands $\left(c\left(\left[{ }^{3} \mathrm{H}\right]\right.\right.$ DAMGO $)=4 \mathrm{nM}$ and $\mathrm{c}\left(\left[{ }^{3} \mathrm{H}\right]\right.$ naloxone $\left.)=2 \mathrm{nM}\right)$ in separate experiments. The inhibition of radioligand binding in three MOR-rich brain regions (thalamus, striatum, and presubicu- 
a

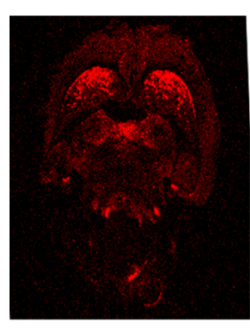

e

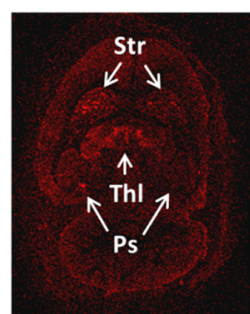

b

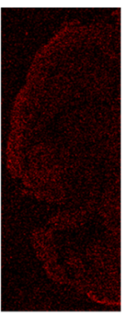

f

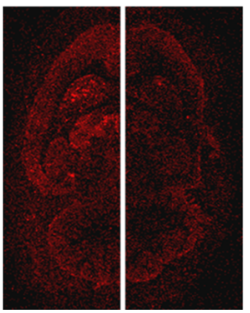

C

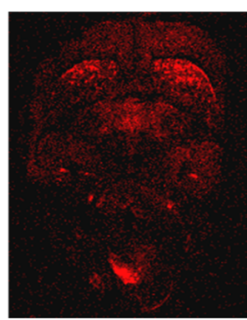

g

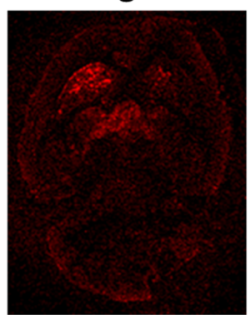

d

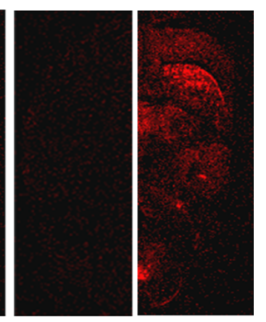

h

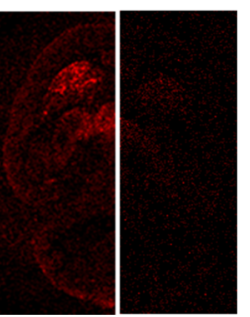

Figure 3. AR images obtained with $\left[{ }^{3} \mathrm{H}\right] \mathrm{DAMGO}$ : (a) in the absence of $3 \mathbf{b}$ (4 $\mathrm{nM}$ radioligand only, control), (b) direct comparison between the control (on right) and in the presence of $3 \mathbf{b}(1 \mu \mathrm{M})$ on the left, (c) in the absence of $3 \mathbf{e}(4 \mathrm{nM}$ radioligand only, control), (d) direct comparison between the control (on right) and in the presence of $3 \mathbf{e}(1 \mu \mathrm{M})$ on the left and with $\left[{ }^{3} \mathrm{H}\right]$ naloxone: $(\mathrm{e})$ in the absence of $3 \mathbf{b}(2 \mathrm{nM}$ radioligand only, control), (f) direct comparison between the control (on left) and in the presence of $3 \mathbf{b}(1 \mu \mathrm{M})$ on the right, $(\mathrm{g})$ in the absence of $3 \mathbf{e}(2 \mathrm{nM}$ radioligand only, control), and $(\mathrm{h})$ direct comparison between the control (on left) and in the presence of $3 \mathrm{e}(1 \mu \mathrm{M})$ on the right. Str = striatum; Thl = thalamus; Ps = presubiculum.

Table 2. Direct Comparison between Inhibition Constant $\left(K_{\mathrm{i}}\right)$ and $\mathrm{IC}_{50}$ Values for $3 \mathrm{~b}$ and $3 \mathrm{e}$

\begin{tabular}{|c|c|c|c|c|c|c|c|c|}
\hline \multirow[b]{3}{*}{ region } & \multicolumn{4}{|c|}{$3 \mathbf{b}$} & \multicolumn{4}{|c|}{$3 e$} \\
\hline & \multicolumn{2}{|c|}{$\left[{ }^{3} \mathrm{H}\right]$ naloxone } & \multicolumn{2}{|c|}{$\left[{ }^{3} \mathrm{H}\right] \mathrm{DAMGO}$} & \multicolumn{2}{|c|}{$\left[{ }^{3} \mathrm{H}\right]$ naloxone } & \multicolumn{2}{|c|}{$\left[{ }^{3} \mathrm{H}\right] \mathrm{DAMGO}$} \\
\hline & $\mathrm{IC}_{50} / \mathrm{nM}$ & $K_{\mathrm{i}} / \mathrm{nM}$ & $\mathrm{IC}_{50} / \mathrm{nM}$ & $K_{\mathrm{i}} / \mathrm{nM}$ & $\mathrm{IC}_{50} / \mathrm{nM}$ & $K_{\mathrm{i}} / \mathrm{nM}$ & $\mathrm{IC}_{50} / \mathrm{nM}$ & $K_{\mathrm{i}} / \mathrm{nM}$ \\
\hline thalamus & 831 & 86 & 1455 & 79 & 485 & 50 & 888 & 48 \\
\hline striatum & 887 & 84 & 1238 & 62 & 250 & 24 & 812 & 40 \\
\hline presubiculum & 1080 & 137 & 1890 & 128 & 286 & 37 & 829 & 58 \\
\hline
\end{tabular}

Scheme 1. Reaction Scheme for Radiosynthesis of $\left[{ }^{18} \mathrm{~F}\right] 3 \mathrm{~b}$ and $\left[{ }^{18} \mathrm{~F}\right] 3 \mathrm{e}$

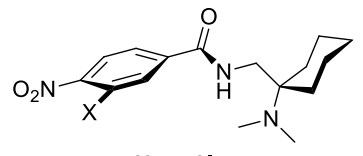

$3 \mathbf{k}$ or $3 \mathbf{1}$

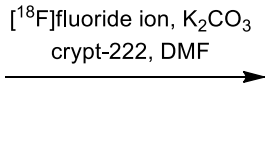

F]fluoride ion, $\mathrm{K}_{2} \mathrm{CO}_{3}$

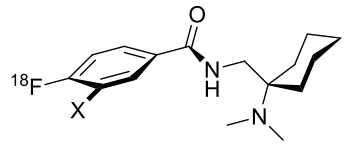

$3 b$ or $3 e$ lum) was studied, and $\mathrm{IC}_{50}$ curves were obtained (Supporting Information, Figure S19).

A considerable reduction in the binding of both radioligands by $\mathbf{3 b}$ and $\mathbf{3 e}$ is observed in the thalamus, striatum, and presubiculum, in the presence of ascending concentrations of the test compounds. In comparison, a negligible effect is seen in the cerebellum, which is known to have negligible OR expression. As shown in the AR images (Figure $3 a-h$ ), at 1 $\mu \mathrm{M}$ concentration of both ligands, inhibition of binding is near quantitative in $\left[{ }^{3} \mathrm{H}\right]$ DAMGO images (Figure $3 \mathrm{a}-\mathrm{d}$ ) compared to the $\left[{ }^{3} \mathrm{H}\right]$ naloxone at the same concentration (Figure $3 \mathrm{e}-\mathrm{h}$ ), where some dispersed binding is visible. This could be explained by a lower sensitivity of the antagonist ligand (naloxone) to agonist ( $\mathbf{3 b}$ and $\mathbf{3 e}$ ) competition, as has also been shown in earlier studies. ${ }^{5-8}$ AR images obtained in the presence of $3 \mu \mathrm{M}$ diprenorphine were used to define the nonspecific binding of the radioligands, which was at a similar level to the binding observed in the presence of $1 \mu \mathrm{M} 3 \mathbf{b}$ and $3 \mathbf{e}$. Although a drop in radioligand binding (about -20\%) was consistently observed at low $\mathrm{nM}$ concentration between 1 and $10 \mathrm{nM}$, curve fits did not converge for a two-site binding model, either owing to variability of the AR binding between replicates or because of the lack of lower concentrations $(0.3$ or $0.1 \mathrm{nM})$. The observed drop may represent binding to the activated receptor which makes up for a minority of the MOR expression. The near complete displacement of both radioligands from the nonactivated receptor representing the majority of MOR protein at high concentration of $\mathbf{3 b}$ or $\mathbf{3 e}$ concentrations would imply that the test compounds bind with high affinity to the active MOR state present in low concentration (1-10 nM, 20\% displacement) and with low affinity to the excess nonactivated state (near complete displacement at $1000 \mathrm{nM}$ ).

A comparison of $\mathrm{IC}_{50}$ and $K_{\mathrm{i}}$ values obtained by receptor binding studies using rat brain $\mathrm{AR}$ of the lead compound 3a against both $\mathbf{3 b}$ and $3 \mathbf{e}$ are presented in Table 2 .

Because $\mathbf{3 b}$ and $\mathbf{3 e}$ revealed adequate MOR-selective binding and agonist activity in vitro, we proceeded with radiolabeling of $\mathbf{3 b}$ and $3 \mathbf{e}$ with ${ }^{18} \mathrm{~F}$ and evaluated the radioligands in rat by $e x$ vivo $\mathrm{AR}$ and in vivo small-animal $\mathrm{PET}$. 

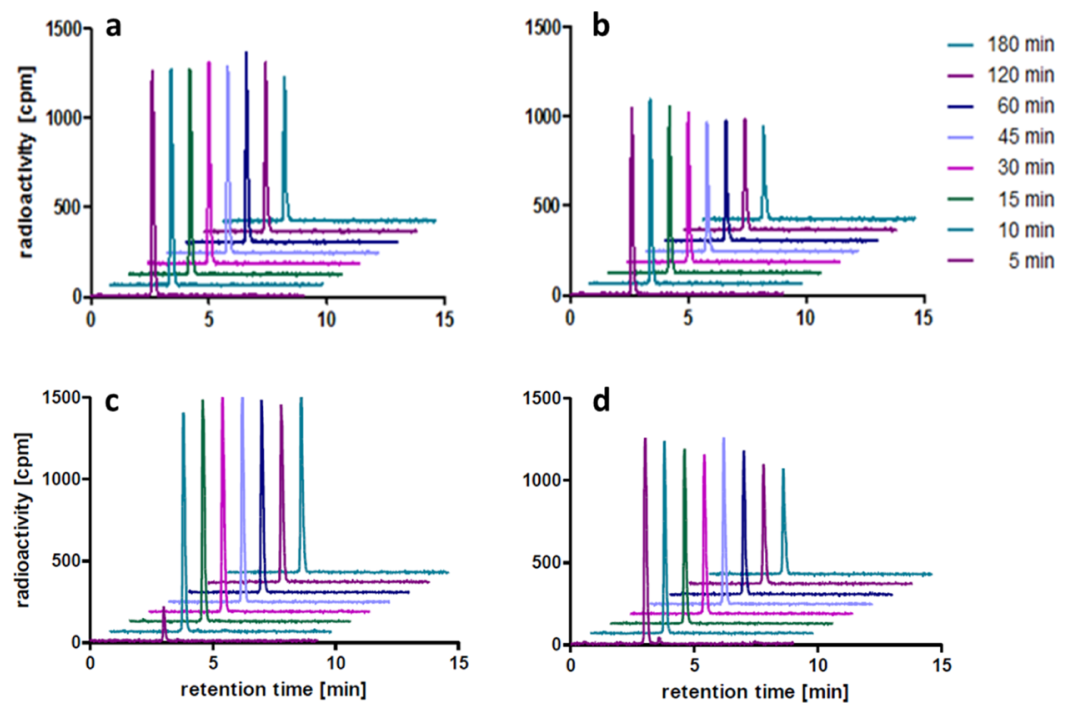

Figure 4. In vitro stability of $\left[{ }^{18} \mathrm{~F}\right] \mathbf{3 b}$ determined by radio-HPLC in human serum (a) and rat plasma (b) and $\left[{ }^{18} \mathrm{~F}\right] 3 \mathbf{e}$ in human serum (c) and rat plasma (d) at different time points.
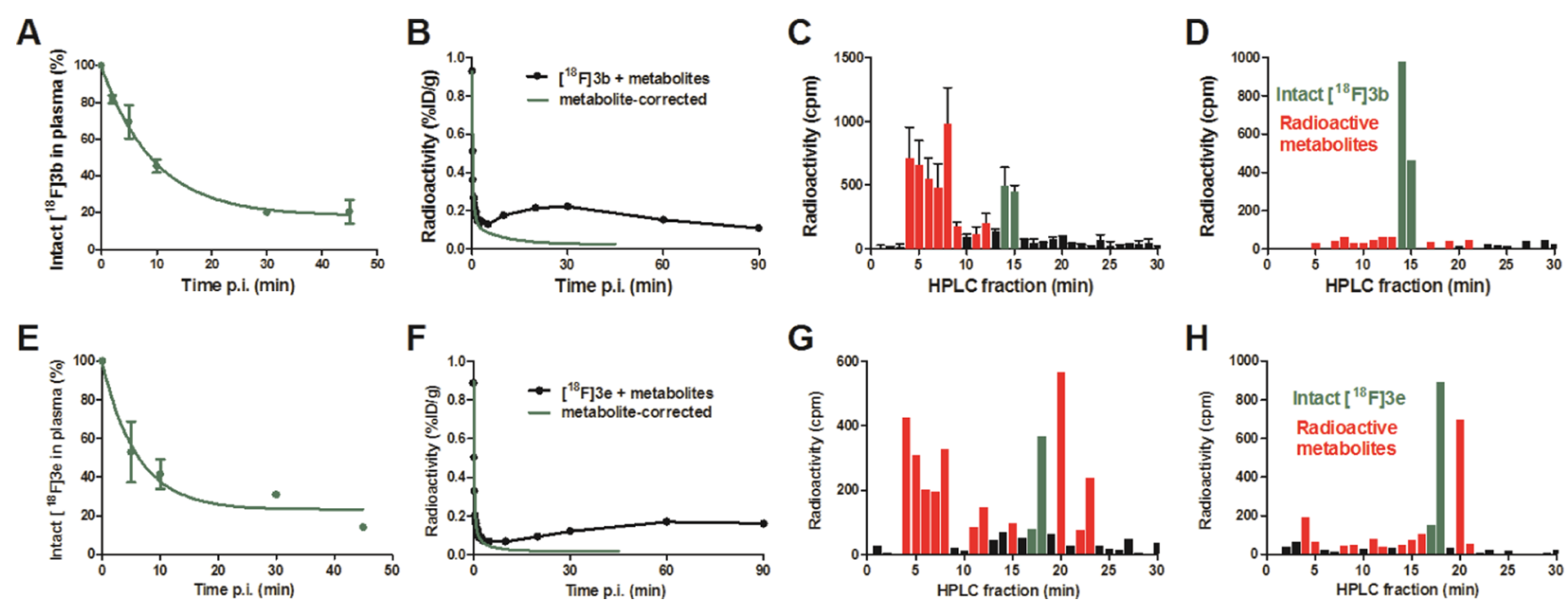

Figure 5. In vivo stability in rats and metabolite correction of the plasma concentration of $\left[{ }^{18} \mathrm{~F}\right] \mathbf{3 b}(\mathrm{A}-\mathrm{D})$ and $\left[{ }^{18} \mathrm{~F}\right] \mathbf{3 e}(\mathrm{E}, \mathrm{F})$ : intact $\left[{ }^{18} \mathrm{~F}\right] \mathbf{3 b}$ in plasma (A), total and metabolite-corrected plasma input for $\left[{ }^{18} \mathrm{~F}\right] 3 \mathbf{b}(\mathrm{B})$, plasma metabolite profile of $\left[{ }^{18} \mathrm{~F}\right] 3 \mathbf{b}$ at 45 min p.i. (C), brain metabolite profile of $\left[{ }^{18} \mathrm{~F}\right] 3 \mathbf{b}$ at $45 \mathrm{~min}$ p.i. (D), intact $\left[{ }^{18} \mathrm{~F}\right] 3 \mathbf{e}$ in plasma $(\mathrm{E})$, total and metabolite-corrected plasma input for $\left[{ }^{18} \mathrm{~F}\right] 3 \mathbf{e}(\mathrm{F})$, plasma metabolite profile of $\left[{ }^{18} \mathrm{~F}\right]$ $3 \mathbf{e}$ at $45 \mathrm{~min}$ p.i. $(\mathrm{G})$, and brain metabolite profile of $\left[{ }^{18} \mathrm{~F}\right] 3 \mathbf{e}$ at $45 \mathrm{~min}$ p.i. $(\mathrm{H})$; radio-HPLC fractions containing metabolites are shown in red, and fractions containing the intact tracer are shown in green.

Radiosynthesis of $\left[{ }^{18} \mathrm{~F}\right] 3 \mathrm{~b}$. The radiosynthesis of $\left[{ }^{18} \mathrm{~F}\right] \mathbf{3 b}$ started with the nitro precursor $3 \mathbf{k}$, which underwent cryptatemediated nucleophilic substitution with n.c.a. $\left[{ }^{18} \mathrm{~F}\right]$ fluoride (Scheme 1). The reaction conditions were optimized by methodological variation of reaction parameters to preserve the radiochemical yield (RCY) and product quality (see the Supporting Information). Using the optimized reaction conditions (DMF as a solvent and 8 min reaction time at 150 $\left.{ }^{\circ} \mathrm{C}\right),\left[{ }^{18} \mathrm{~F}\right] 3 \mathbf{b}$ was obtained in a reproducible RCY of $75 \pm 3.5 \%$. After high-performance liquid chromatography (HPLC) purification and formulation in a total synthesis time of 75 min, $\left[{ }^{18} \mathrm{~F}\right] \mathbf{3 b}$ was obtained in $21 \pm 5 \% \mathrm{RCY}$ and a radiochemical purity of $>98 \%$. In order to avoid overloading of the HPLC column, only $3.5 \mathrm{mg}$ of the labeling precursor was used as a compromise between RCY and the efficient purification of the reaction mixture. The molar radioactivity of $\left[{ }^{18} \mathrm{~F}\right] 3 \mathbf{b}$ at the end of synthesis ranged from 10 to $18 \mathrm{GBq} / \mu \mathrm{mol}(n=4$; Erlangen lab) or 25 to $40 \mathrm{GBq} / \mu \mathrm{mol}(n=5$; Oslo lab).
Radiosynthesis of $\left[{ }^{18} \mathrm{~F}\right] 3 \mathrm{e}$. When $\left[{ }^{18} \mathrm{~F}\right] 3 \mathrm{e}$ was prepared using the conditions developed for $\left[{ }^{18} \mathrm{~F}\right] \mathbf{3 b}$, a high amount of nonradioactive reference compound $3 \mathrm{e}(54 \mu \mathrm{g}, 157 \mathrm{nmol} / \mathrm{mL})$ was observed in the reaction mixtures. Because $\left[{ }^{18} \mathrm{~F}\right] 3 \mathrm{e}$ was synthesized through direct nucleophilic radiofluorination of 3trifluoro-4-nitro- $N$-(1-(dimethylamino) cyclohexyl)methyl benzamide, 31, we surmised that the fluoride ion was released from the trifluoromethyl group in 31 . Control experiments confirmed that degradation of 31 resulted in the release of nonradioactive fluoride during labeling. This was then mitigated by optimization of temperature and time, and $\left[{ }^{18} \mathrm{~F}\right] 3 \mathbf{e}$ was obtained in a nondecay-corrected RCY of $23 \pm 4(n=6)$ at $75{ }^{\circ} \mathrm{C}$ for 3 $\mathrm{min}$, in a molar radioactivity of $250-300 \mathrm{GBq} / \mu \mathrm{mol}$ with a chemical and radiochemical purity of $>97 \%$.

In Vitro and in Vivo Stability of $\left[{ }^{18} \mathrm{~F}\right] 3 \mathrm{~b}$ and $\left[{ }^{18} \mathrm{~F}\right] 3 \mathrm{e}$. The stability of $\left[{ }^{18} \mathrm{~F}\right] \mathbf{3 b}$ and $\left[{ }^{18} \mathrm{~F}\right] \mathbf{3} \mathbf{b}$ was assayed in formulation. Through periodic analysis of the radiotracer formulation with radio-HPLC and radio thin-layer chromatography (radio-TLC), 
A

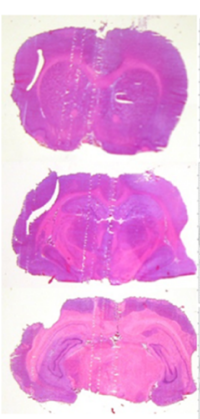

HE

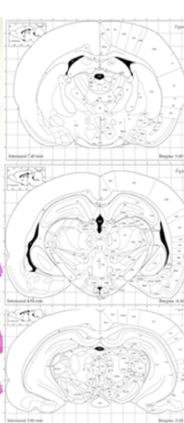
(c)

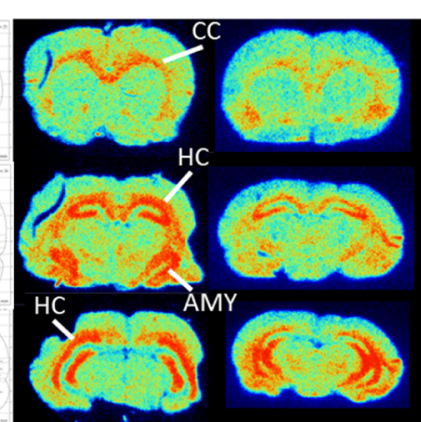

$\left[{ }^{18} \mathrm{~F}\right] \mathbf{3 b}$

$\left[{ }^{18} \mathrm{~F}\right] \mathbf{3 b} /$
B

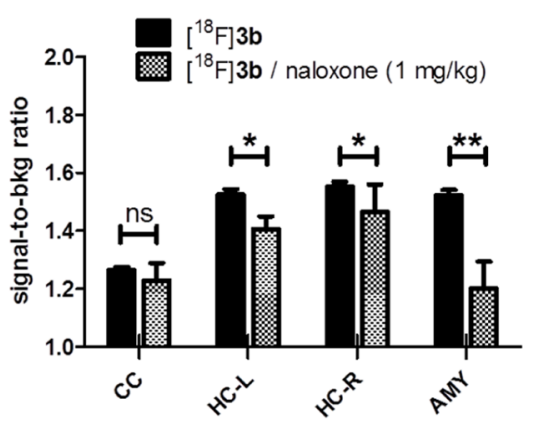

Figure 6. Ex vivo AR of coronal rat brain slices at $45 \mathrm{~min}$ p.i. of $\left[{ }^{18} \mathrm{~F}\right] 3 \mathbf{b}$ and $\left[{ }^{18} \mathrm{~F}\right] 3 \mathbf{b}$ coinjected with naloxone $(1 \mathrm{mg} / \mathrm{kg}):(\mathrm{A})$. HE staining of the corresponding rat brain slices and reference brain region diagrams from the rat brain atlas by Paxinos and Watson ${ }^{23}$ are shown for comparison. Analysis of rat brain AR from a single experiment, comparing the injection of $\left[{ }^{18} \mathrm{~F}\right] 3 \mathbf{b}$ alone with the coinjection of $\left[{ }^{18} \mathrm{~F}\right] 3 \mathbf{b} /$ naloxone (B). Values are shown as mean $\pm \mathrm{SD}(\mathrm{CC}=$ corpus callosum $(n=27 v s n=16), \mathrm{HC}-\mathrm{L}=$ left hippocampus $(n=13 v s n=7), \mathrm{HC}-\mathrm{R}=$ right hippocampus $(n=13 v s n=7), \mathrm{AMY}=$ amygdala $(n=13$ vs $n=7) ; * P<0.05, * * P<0.0001$, ns = not significant $)$.

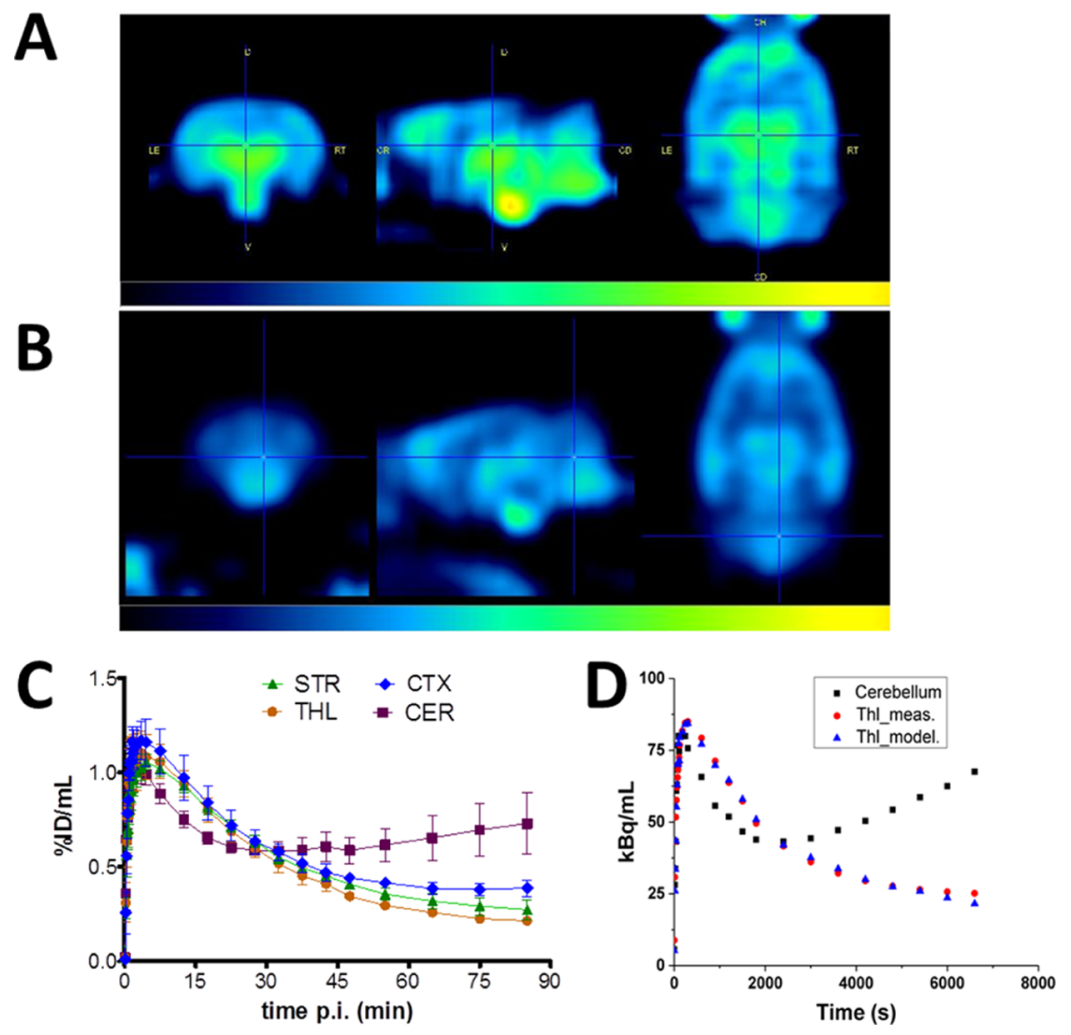

Figure 7. $\mu \mathrm{PET}$ image of a rat brain at $10-30 \mathrm{~min}$ p.i. of $\left[{ }^{18} \mathrm{~F}\right] 3 \mathrm{~b}$ in coronal (A, left), sagittal (A, middle), and transversal projection (A, right) in comparison with the $\mu \mathrm{PET}$ image of a rat brain after naloxone pretreatment $(1 \mathrm{mg} / \mathrm{kg}, 10 \mathrm{~min}$ before the PET scan $)$ at $10-30 \mathrm{~min}$ p.i. of $\left[{ }^{18} \mathrm{~F}\right] 3 \mathbf{b}$ in coronal (B, left), sagittal (B, middle), and transversal projection $(B$, right). Time-activity curves (TACs) for different OR-rich brain regions $(\mathrm{STR}=$ striatum; THL $=$ thalamus; $\mathrm{CTX}=$ cingulate cortex $)$ and the OR-negative region $(\mathrm{CER}=$ cerebellum $)$ after injection of $\left[{ }^{18} \mathrm{~F}\right] 3 \mathbf{b}$ in rats $(n=2-4)(\mathrm{C}$, values are shown as mean $\pm \mathrm{SD})$. Comparison of measured brain uptake values of $\left[{ }^{18} \mathrm{~F}\right] \mathbf{3 b}$ with calculated values derived from the two-tissuecompartment model in the thalamus under baseline conditions of one representative animal ( $D$, note: increasing built-up of cerebellum uptake due to a radioactive metabolite).

both $\left[{ }^{18} \mathrm{~F}\right] \mathbf{3 b}$ and $\left[{ }^{18} \mathrm{~F}\right] \mathbf{3 e}$ were found stable in formulation over a period of $7 \mathrm{~h}$ after the end of synthesis (see the Supporting Information). It was observed that the products are stable for up to $7 \mathrm{~h}$ with radiochemical purities of $>98$ and $>95 \%$, respectively. The stability of both radiotracers was also evaluated in vitro in plasma, and no degradation products were found within $3 \mathrm{~h}$ (Figure 4). The radioligand remained intact in rat blood in vitro ( $>95 \%$ intact parent compound after $2 \mathrm{~h}$ of incubation). This indicates that the radiotracer is not sensible to amide bond cleavage by hydrolase enzymes present in blood. It can be concluded that metabolite determination in rat plasma is not impaired by degradation of the radioligand in blood samples.

Administration of $\left[{ }^{18} \mathrm{~F}\right] 3 \mathbf{b}$ and $\left[{ }^{18} \mathrm{~F}\right] 3 \mathbf{e}$ in rats revealed that 21 $\pm 7 \%$ of $\left[{ }^{18} \mathrm{~F}\right] 3 \mathrm{~b}$ and $16 \pm 5 \%$ of $\left[{ }^{18} \mathrm{~F}\right] 3 \mathrm{e}$ were found intact in blood at $45 \mathrm{~min}$ p.i. (see Figure $5 \mathrm{~A}$ for $\left[{ }^{18} \mathrm{~F}\right] 3 \mathrm{~b}$ and Figure $5 \mathrm{E}$ for $\left.\left[{ }^{18} \mathrm{~F}\right] 3 \mathbf{e}\right)$. The arterial blood of four rats was analyzed at different 
A

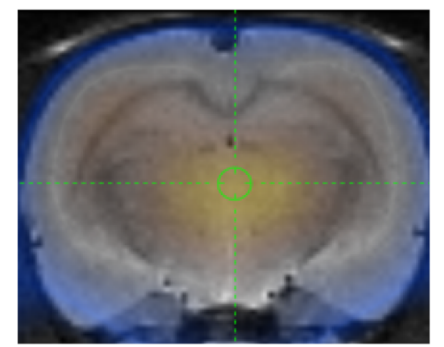

C

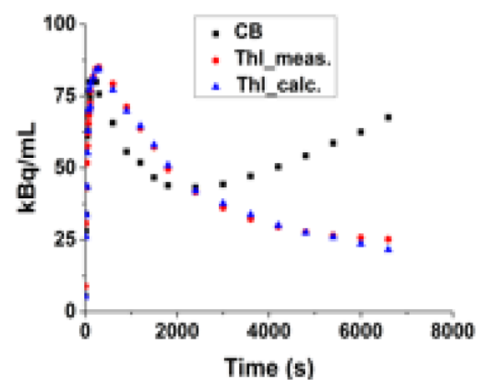

B

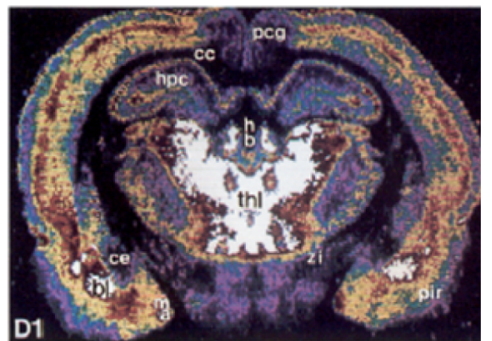

D

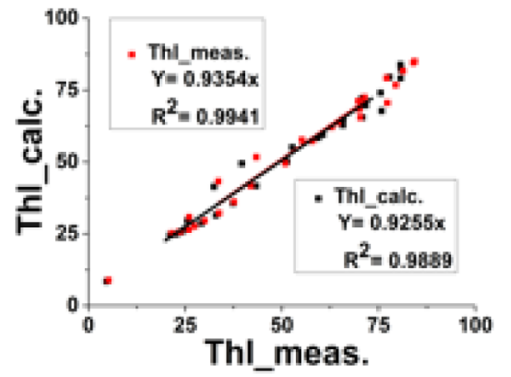

Figure 8. Direct comparison between the $\mu \mathrm{PET}$ image of $\left[{ }^{18} \mathrm{~F}\right] 3 \mathrm{~b}(\mathrm{~A})$ and previously published in vitro AR image in coronal view (B, from Mansour A et al., ${ }^{4}$ with permission from the society of neuroscience). Plasma metabolite concentration over time in comparison to that of the thalamus and cerebellum (C); plot of measured vs calculated TAC values for the thalamus (D).

time points after intravenous injection of the radioligands in separate experiments. The blood samples were processed and analyzed by radio-HPLC to determine the fraction of the intact radiotracer in plasma at different time points. A major portion of radiometabolites observed in both radiotracers were mostly hydrophilic (Figure 5C,G), except one additional metabolite peak which eluted after the parent compound in $\left[{ }^{18} \mathrm{~F}\right] 3 \mathrm{e}$. The observed hydrophilic radiometabolites are in good accordance with the metabolism of the lead compound AH-7921 in urine, as has been published recently. ${ }^{22}$ However, the reported metabolism of AH-7921 suggested the presence of the $\mathrm{N}$ desmethyl metabolites of $\left[{ }^{18} \mathrm{~F}\right] 3 \mathbf{b}$ and $\left[{ }^{18} \mathrm{~F}\right] \mathbf{3 e}$, which were difficult to separate from the intact radioligand, as demonstrated by HPLC (Supporting Information, Figure S18). Additionally, the time course of degradation of the radiotracers was determined by radio-HPLC analysis of the plasma samples from rats that were taken at different time points after tracer injection. ${ }^{7,13}$ A nonlinear curve fit of the measured data was applied to the plasma activity curve to determine the metabolitecorrected plasma input function of the radiotracers (Figure $5 \mathrm{~B}, \mathrm{~F}$ ). No polar radiometabolites were detected in brain tissue up to a time point of $45 \mathrm{~min}$ p.i. for $\left[{ }^{18} \mathrm{~F}\right] 3 \mathrm{~b}$ (Figure $5 \mathrm{D}$ ), whereas radiometabolite brain uptake was observed for $\left[{ }^{18} \mathrm{~F}\right] 3 \mathrm{e}$ (Figure $5 \mathrm{H}$ ), resulting in undefined distribution and troublesome quantification of the true signal of $\left[{ }^{18} \mathrm{~F}\right] 3 \mathrm{e}$ in the brain.

Ex Vivo AR and PET Imaging Studies. With the formulated radiotracers at hand, we proceeded with ex vivo AR and in vivo imaging studies for the quantification of the MOR in rats by PET. For ex vivo AR, two rats were injected with 10-12 $\mathrm{MBq}$ of either $\left[{ }^{18} \mathrm{~F}\right] 3 \mathrm{~b}$ or $\left[{ }^{18} \mathrm{~F}\right] 3 \mathrm{e}$ and sacrificed at $45 \mathrm{~min}$ p.i. The brains were harvested and sliced to obtain the coronal sections for AR studies. Consecutive sections from the animals were obtained and stained to make the anatomy of each section visible. Ex vivo AR images clearly showed uptake of both radiotracers in regions known to express the MOR, such as the pyramidal cell layers of the hippocampus and the amygdala and the endopiriform nucleus (Figure 6). ${ }^{23}$ The single rat that was coinjected with $\left[{ }^{18} \mathrm{~F}\right] \mathbf{3 b}$ and naloxone $(1 \mathrm{mg} / \mathrm{kg})$ showed slightly decreased tracer uptake in MOR-rich brain regions, such as in the amygdala (approximately 20\%), suggesting MORspecific brain uptake of $\left[{ }^{18} \mathrm{~F}\right] 3 \mathbf{b}$ (Figure $6 \mathrm{~B}$ ). However, the competition of naloxone with the radioligand $\left[{ }^{18} \mathrm{~F}\right] 3 \mathbf{b}$ was not pronounced; this may have been due to the different brain uptake kinetics of naloxone and $\left[{ }^{18} \mathrm{~F}\right] \mathbf{3 b}$ such that the effective concentration of naloxone in the brain when coinjected was not sufficient to achieve competition at this time point.

In vivo PET imaging, following well-known terms and methods, ${ }^{23-26}$ of Sprague-Dawley rats revealed high integral brain uptake of up to $1.2 \% \mathrm{ID} / \mathrm{g}\left[{ }^{18} \mathrm{~F}\right] 3 \mathrm{~b}$ in the time frame of 5$10 \mathrm{~min}$ p.i (Figure $7 \mathrm{C}$ ), confirming the prediction of adequate brain uptake by the in vitro data on lipophilicity and polarity of 3b. The PET images showed uptake of $\left[{ }^{18} \mathrm{~F}\right] 3 \mathbf{b}$ in OR-rich brain regions (Figure $7 \mathrm{~A}$ ), such as the striatum, thalamus, and cingulate cortex. Following coinjection $(n=2)$ and pretreatment $(n=2)$, with naloxone $(1 \mathrm{mg} / \mathrm{kg}) 10 \mathrm{~min}$ prior to injection of $\left[{ }^{18} \mathrm{~F}\right] \mathbf{3} \mathbf{b}$ for blocking of OR availability, the binding potential of $\left.{ }^{18} \mathrm{~F}\right] 3 \mathbf{b}$ was diminished in the thalamus region of interest (ROI) by 47 and $73 \%$, respectively (Figures $7 \mathrm{~B}$ and S50). In PET scans of rats, radioactivity in MOR-rich regions decreased less rapidly compared to the curve of the cerebellum, which is low in the $\mathrm{MOR}$, up to $30 \mathrm{~min}$ p.i (Figure $7 \mathrm{C}$ ). At the end of a 45 min scan, a mere $31 \%$ of the initial activity concentration is measured. In contrast, maximum radioactivity concentration of $\left[{ }^{18} \mathrm{~F}\right] 3 \mathbf{b}$ in the thalamic region of $1 \% \mathrm{ID} / \mathrm{mL}$ is reached after $10 \mathrm{~min}$ during baseline scans (Figure 7C). It remains higher than that of the cerebellum until $30 \mathrm{~min}$ p.i., when increasing built-up of a radiometabolite in the cerebellum confounds its use as a reference region (Figure 7D). Nonetheless, model curves obtained via reference input kinetic modeling produced good fits of the experimentally obtained time activity curves for the baseline and block (Figure S50). For baseline scans, a $\mathrm{BP}_{\mathrm{ND}}$ value of $0.185 \pm 0.025$ was obtained using the simplified reference tissue model 2 (SRTM2) in pmod 3.8. Coinjection of $1 \mathrm{mg} / \mathrm{kg}$ naloxone reduced the $\mathrm{BP}_{\mathrm{ND}}$ to $0.08 \pm 0.029$, whereas 
pretreatment for $10 \mathrm{~min}$ p.i. using the same dose reduced the $\mathrm{BP}_{\mathrm{ND}}$ to $0.05 \pm 0.01$ (Supporting Information).

Although the $\mathrm{BP}_{\mathrm{ND}}$ is sensitive to competition with naloxone, it is lower than that of $\left[{ }^{11} \mathrm{C}\right]$ carfentanil, and this can be ascribed to the low affinity of the radioligand; maximal $\mathrm{BP}_{\mathrm{ND}}$ achievable with the high affinity ligand $\left[{ }^{11} \mathrm{C}\right]$ carfentanil is about $10-20$ times higher, which is in line with about 10 -fold to 20-fold higher $K_{\mathrm{d}}$. The parent 3a has a $K_{\mathrm{d}}$ of $1.8 \mathrm{nM}$, whereas carfentanil lies in the range of $0.03-0.08 \mathrm{nM}^{6-8,15}$

Summed PET images of $\left[{ }^{18} \mathrm{~F}\right] \mathbf{3 b}$ in early frames, for example, 10-30 min, showed binding patterns in good accordance with the pattern observed for $\left[{ }^{11} \mathrm{C}\right] 3 \mathrm{a}^{8}$ We were pleased to observe close similarity of the regional distribution of $\left[{ }^{18} \mathrm{~F}\right] 3 \mathbf{b}$ in the PET image (Figure $8 \mathrm{~A}$ ) compared with the reported in vitro AR using $\left[{ }^{3} \mathrm{H}\right]$ DAMGO (Figure $\left.8 \mathrm{~B}\right) .{ }^{4}$ Using $\left[{ }^{18} \mathrm{~F}\right] 3 \mathbf{b}$, even the uptake in individual cortical laminae expressing MOR (Figure 8A) was resolved. As hypothesized in the ligand design, the PET data indicated rapid uptake of the radioligand into the brain peaking at $5 \mathrm{~min}$ p.i., in conjunction with a steady washout over $45 \mathrm{~min}$ and some retention of activity in MOR-rich domains of the central nervous system. An MOR-dominated pattern of radioligand binding and considerable retention in the corresponding brain regions was observed, albeit with moderate contrast between regions. When analyzing late time frames after $60 \mathrm{~min}$, the radioactivity distribution pattern of $\left[{ }^{18} \mathrm{~F}\right] 3 \mathrm{~b}$ was biased toward cortical and cerebellar uptake, as illustrated by ascending time-activity curves of these regions (Figure 7, lower right). This phenomenon was ascribed to the presence of radioactive metabolites of $\left[{ }^{18} \mathrm{~F}\right] \mathbf{3 b}$ in the brain, irreversibly binding to structures in the cerebellum and the cortex.

Kinetic analysis of the PET data was also attempted to quantify binding of $\left[{ }^{18} \mathrm{~F}\right] \mathbf{3 b}$ in the rat brain. ${ }^{7-10,13}$ When the two-tissue compartment model was used, excellent fits were obtained for blood and plasma input of the intact tracer in the thalamus (Figure 8C,D). Nonetheless, high plasma metabolite concentration was apparent, peaking $16 \mathrm{~min}$ p.i. The metabolite appeared to enter the brain and accumulated in the cerebellum and cortex. This uptake was not affected by pretreatment with the OR antagonist, indicating binding to a non-OR binding site.

In scans lasting up to $60 \mathrm{~min}$ p.i., a plot of the measured $v s$ the modeled values gives inclines of 0.94 for thalamus and 0.93 for caudate putamen (Figure $8 \mathrm{D}$ ), which translates into a slight underestimation of the binding potential in the two-tissue compartment model. Nonetheless, model curves obtained via reference input kinetic modeling produced good fits of the experimentally obtained time activity curves for the baseline and block (Figure S50). For baseline scans, a $\mathrm{BP}_{\mathrm{ND}}$ value of $0.185 \pm$ 0.025 was obtained using the simplified reference tissue model 2 (SRTM2) in pmod 3.8. Coinjection of $1 \mathrm{mg} / \mathrm{kg}$ naloxone reduced the $\mathrm{BP}_{\mathrm{ND}}$ to $0.08 \pm 0.029$ (minus $57 \%$ ), whereas naloxone pretreatment 10 min before radiotracer administration using the same dose reduced the $\mathrm{BP}_{\mathrm{ND}}$ to $0.05 \pm 0.01$ (minus $73 \%)$ (Supporting Information). These results are in line with displacements published in the literature. ${ }^{8,21}$ Although somewhat decent fits were obtained for some animals using SRTM2 up to $40 \mathrm{~min}$ p.i., inclusion of later time points (post $40 \mathrm{~min}$ ) into reference tissue modeling did not lead to any useful results, owing to the absence of a reference region without interfering uptake of radioactivity. We, hence, separated the plasma metabolite from the intact tracer and attempted to model the uptake of the radiometabolite. Indeed, we found that the metabolite adhered to an irreversible kinetic profile, which explains the continuous uptake during the entire length of the PET scan.

For in vivo $\mathrm{PET}$ imaging with $\left[{ }^{18} \mathrm{~F}\right] \mathbf{3 e}$, the radioligand was administered as a bolus injection to Sprague-Dawley rats via the tail vein, and PET data were recorded for up to $120 \mathrm{~min}$. Reconstructed imaging data were coregistered to an anatomical atlas of the rat brain normalized to MNI space to draw the ROIs. The radioactivity concentrations in different regions of the brain, for example, thalamus and cerebellum, were extracted to obtain the time-activity curves (Figure 9B). The time-activity

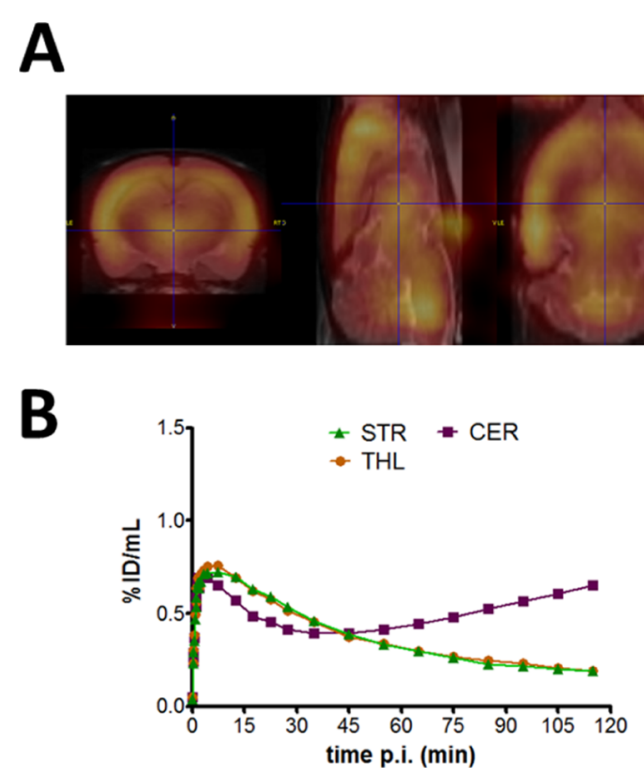

Figure 9. $\mu \mathrm{PET}$ image of a rat brain at $10-30 \mathrm{~min}$ p.i. of $\left[{ }^{18} \mathrm{~F}\right] 3 \mathrm{e}$ in coronal (left), horizontal (middle), and transversal projection (right) under baseline conditions (A) and the time-activity curve of one rat scanned for $120 \mathrm{~min}$ p.i. (B).

curves show a rapid brain uptake of about $0.75 \% \mathrm{ID} / \mathrm{mL}$ in brain regions within $5 \mathrm{~min}$ of $\left[{ }^{18} \mathrm{~F}\right] 3 \mathrm{e}$ injection (Figure $9 \mathrm{~B}$ ). Activity concentrations in the thalamus, cingulate cortex, and other regions rich in MOR equilibrate within $10 \mathrm{~min}$ p.i., after which a steady washout is observed in most key regions. In late time frames (50-60 min p.i.), increasingly high radioactivity concentration was observed in the cerebellum and cortex because of the presence of an irreversibly binding radioactive metabolite. However, summed images between 10 and $40 \mathrm{~min}$ p.i. clearly mirror the MOR distribution, as shown in Figure 9A. Unfortunately, we had to exclude $\left[{ }^{18} \mathrm{~F}\right] 3 \mathrm{e}$ from further study because of the presence of lipophilic radiometabolites in brain tissue throughout the scan.

\section{CONCLUSIONS}

A series of novel MOR-selective analogues based on the benzamide scaffold AH-7921 were designed to accommodate convenient sites for direct nucleophilic radiofluorination. Compounds were tested for agonist binding and potency toward the human DOR, KOR, and MOR. Two potential candidates from the series were selected and scrutinized for their potential as PET radiotracers for the efficient and rapid quantification of the MOR in living subjects.

Compounds $\left[{ }^{18} \mathrm{~F}\right] 3 \mathbf{b}$ and $\left[{ }^{18} \mathrm{~F}\right] 3 \mathbf{e}$ were synthesized via an automated process and prepared in a sterile formulation using a straightforward methodology available in numerous other PET centers. The radioligands were obtained in sufficient RCY and 
quality for routine application, and no adverse degradation of the compound was observed in blood plasma or in formulation. Receptor binding studies demonstrated moderate affinity of the radioligands, which translates into fast biokinetics in vivo. In vitro receptor activation studies indicated high selectivity for the MOR compared to other potential targets, and pronounced receptor activation, characteristic for agonistic effects on the receptor, was detected for all three OR subtypes when expressed in $\mathrm{CHO}-\mathrm{K} 1$ cells. The in vivo evaluation of $\left[{ }^{18} \mathrm{~F}\right] 3 \mathbf{b}$ and $\left[{ }^{18} \mathrm{~F}\right] 3 \mathbf{e}$ showed a regional brain distribution in accordance with the $\mathrm{OR}$ distribution in the rat brain. However, quantification of $\mathrm{BP}_{\mathrm{ND}}$ was complicated by a very rapid washout, and only low $\mathrm{BP}_{\mathrm{ND}}$ was obtained, paired with brain penetrating, irreversibly binding the radiometabolite. Although the radiometabolite adheres to an irreversible kinetic profile and continuously piles up in the brain during the entire length of the PET scan, blocking of $\left[{ }^{18} \mathrm{~F}\right] 3 \mathrm{~b}$ binding was possible and the quantification of PET data was feasible using the metabolite-corrected blood input function. However, on the other hand, quantification of $\left[{ }^{18} \mathrm{~F}\right] 3 \mathbf{e}$ was not devoid of troubles because of the high radioactivity concentration in the brain confounding with the true tracer uptake. On the basis of our findings, we conclude that 3 a may provide a suitable scaffold for development of ${ }^{18}$ F-labeled OR PET radiotracers with a fast kinetic profile for the in vivo imaging and quantification of the MOR in preclinical PET imaging studies.

\section{EXPERIMENTAL SECTION}

General. Standard solvents and reagents used in the experiments described herein were procured from Sigma-Aldrich (Sigma-Aldrich AS, Norway) in analytical quality unless specified otherwise. The starting material 3-chloro-4-nitrobenzoyl chloride was purchased from FCH (FCH group, Chernigove, Ukraine). Solid-phase extraction cartridges were purchased from VWR (VWR International, Darmstadt, Germany).

Nuclear magnetic resonance spectra were recorded on a Bruker AVII 400 NMR instrument (Bruker ASX Nordic AB). Chemical shifts $(\delta)$ for ${ }^{1} \mathrm{H}(400 \mathrm{MHz})$ and ${ }^{13} \mathrm{C}(100 \mathrm{MH})$ resonances are reported in parts per million (ppm), relative to the solvent signal $\left(\mathrm{CDCl}_{3} \delta=7.223 \mathrm{ppm}\right)$, downfield from a theoretical tetramethylsilane signal (TMS, $\delta=0$ $\mathrm{ppm})$. Mass spectrometry was conducted on a Q-Tof-2 mass analyzer (Micromass, Q-Tof-2TM) using an ESI ion source in the positive mode. IR spectra were obtained using a Bruker Vertex 70 dual-channel spectrometer (Bruker ASX Nordic AB), and values are expressed in wavenumbers $\nu\left(\right.$ in $\left.\mathrm{cm}^{-1}\right)$.

HPLC analysis of compound purity and quality control was conducted on a Hewlett-Packard 1100 HPLC system (Matriks AS, Agilent Technologies, Oslo, Norway) consisting of a quaternary pump, variable wavelength diode array detector, and a Raytest Gina star radioactivity detector (Raytest GmBH, Straubenhardt, Germany) using GABI-star software (Raytest) for instrument control, data acquisition, and processing. Three HPLC methods were developed. For determination of purity and stability of the formulated radiotracer, a Luna C18(2) column (Phenomenex; $5 \mu \mathrm{m}, 100 \AA$, $250 \mathrm{~mm} \times 4.6 \mathrm{~mm}$ ) with an isocratic mixture of $\mathrm{MeCN}-$ phosphate buffer $(50 \mathrm{mM}$, pH7; 3:7 )was used at a flow rate of $1.8 \mathrm{~mL} / \mathrm{min}$. Alternatively, an HS-F5 column (Supelco; $5 \mu \mathrm{m}, 100 \AA, 250 \mathrm{~mm} \times 4.6 \mathrm{~mm}$ ) and an isocratic mixture of MeCN-formate buffer $(0.1 \mathrm{M}, \mathrm{pH} 7 ; 85: 15)$ at $1.0 \mathrm{~mL} / \mathrm{min}$ flow rate were used. For determination of radiometabolites, a Kromasil C8 column (100 $\AA ; 250 \mathrm{~mm} \times 4.6 \mathrm{~mm})$ in gradient elution using 20 $53.3 \% \mathrm{MeCN}$ (0.1\% TFA) in water (0.1\% TFA) for $25 \mathrm{~min}, 53.3-80 \%$ $\mathrm{MeCN}(0.1 \% \mathrm{TFA})$ in water (0.1\% TFA) for $4 \mathrm{~min}, 80-100 \% \mathrm{MeCN}$ $(0.1 \%$ TFA $)$ in water $(0.1 \%$ TFA $)$ for $1 \mathrm{~min}$, and ending to $100 \%$ $\mathrm{MeCN}(0.1 \% \mathrm{TFA})$ for $4 \mathrm{~min}$. UV signals were detected at a wavelength of $254 \mathrm{~nm}$. Purity of all tested compounds was $>95 \%$, as determined by HPLC UV detection at $254 \mathrm{~nm}$ wavelength. Radio-TLC was conducted on silica gel $60 \mathrm{~F}_{254}$-coated aluminum TLC plates (Merck KGaA, Darmstadt, Germany) using hexanes-ethyl acetate- $\mathrm{Et}_{3} \mathrm{~N}, \quad 7: 3: 1$.
Radio-TLC plates were analyzed using a Raytest miniGita radio-TLC scanner (Raytest GmBH, Straubenhardt Germany). All other radioactivity measurements during labeling experiments and radiotracer productions were performed using an Atomlab 300 dose calibrator (Biodex Medical Systems).

Chemistry. General Procedure for the Preparation of Compounds $3 a-l$. A $50 \mathrm{~mL}$ oven-dried round bottom flask was charged with [1-(N,N-dimethylamino)-cyclohex-1-yl]methylamine hydrochloride $(2,115 \mathrm{mg}, 0.5 \mathrm{mmol})$ in diethyl ether, $\mathrm{Et}_{2} \mathrm{O}(20 \mathrm{~mL})$. Triethylamine, $\mathrm{NEt}_{3}(101.2 \mathrm{mg}, 1 \mathrm{mmol})$, was added, and reaction contents were stirred for $15 \mathrm{~min}$. Benzoyl chlorides $1 \mathrm{a}-\mathbf{1}(0.5 \mathrm{mmol}, 1$ equiv) in $\mathrm{Et}_{2} \mathrm{O}(2 \mathrm{~mL})$ were added dropwise and allowed to react for $6 \mathrm{~h}$ at room temperature. The reaction was quenched with aqueous ammonium hydroxide, $\mathrm{NH}_{4} \mathrm{OH}(30 \%$ in water, $10 \mathrm{~mL})$, and partitioned between $\mathrm{Et}_{2} \mathrm{O}$ and $\mathrm{NH}_{4} \mathrm{OH}(\mathrm{aq})$. Organic extracts were combined, dried over anhydrous sodium sulfate $\left(\mathrm{Na}_{2} \mathrm{SO}_{4}\right)$, and concentrated to dryness in vacuo. The residue products were purified by silica gel $\left(\mathrm{SiO}_{2}\right)$ column chromatography using EtOAc-hexane$\mathrm{Et}_{3} \mathrm{~N}(40: 55: 5 \mathrm{v} / \mathrm{v} / \mathrm{v})$.

3,4-Dichloro-N-\{[1-(dimethylamino)cyclohexyl]methyl $\}$ benzamide (3a). Colorless solid (71\%), $R_{\mathrm{f}}=0.28$ (EtOAc-hexanes$\left.\mathrm{Et}_{3} \mathrm{~N} ; 40: 55: 5\right) ;{ }^{1} \mathrm{H}$ NMR (400 MHz, $\mathrm{CDCl}_{3}$ ): $\delta$ (in ppm) 7.80 (d, $J=$ $2.0 \mathrm{~Hz}, \mathrm{ArH}, 1 \mathrm{H}), 7.52(\mathrm{dd}, J=8.3,2.0 \mathrm{~Hz}, \mathrm{ArH}, 1 \mathrm{H}), 7.43(\mathrm{~d}, J=8.3$ $\mathrm{Hz}, \mathrm{ArH}, 1 \mathrm{H}), 6.91(\mathrm{br} \mathrm{s}, \mathrm{N}-\mathrm{H} 1 \mathrm{H}), 3.46\left(\mathrm{~d}, J=4.6 \mathrm{~Hz}, \mathrm{~N}-\mathrm{CH}_{2}, 2 \mathrm{H}\right)$, $2.21\left(\mathrm{~s}, \mathrm{~N}-\mathrm{CH}_{3}, 6 \mathrm{H}\right), 1.66-1.01\left(\mathrm{~m}, \mathrm{CH}_{2}, 10 \mathrm{H}\right) ;{ }^{13} \mathrm{C}$ NMR $(100$ $\mathrm{MHz}, \mathrm{CDCl}_{3}$ ): $\delta$ (in ppm) 165.0, 135.3, 134.6, 132.7, 130.3, 129.0, 125.9, 57.3, 40.4, 37.3, 28.0, 25.7, 22.2; IR (KBr) $\nu\left(\right.$ in $\left.\mathrm{cm}^{-1}\right): 3323$ (N-H stretch), 3092, 2987, 2926, 2853, 2813, 2780, 1633, 1555, 1457, 1308, 1246; HR-MS (ESI) $m / z$ : calcd for $\mathrm{C}_{16} \mathrm{H}_{22} \mathrm{Cl}_{2} \mathrm{~N}_{2} \mathrm{O}, 328.1109$; found, $329.1197(\mathrm{M}+\mathrm{H})^{+}$; HPLC by UV $(254)$; $>98 \%$.

3-Chloro-4-fluoro- $N$ - $\{[1$-(dimethylamino)cyclohexyl]methyl\}benzamide (3b). Off-white solid (64\%), $R_{\mathrm{f}}=0.25$ (EtOAc-hexanes$\left.\mathrm{Et}_{3} \mathrm{~N} ; 40: 55: 5\right) ;{ }^{1} \mathrm{H} \mathrm{NMR}\left(400 \mathrm{MHz}, \mathrm{CDCl}_{3}\right): \delta$ (in ppm) 7.85 (dd, $J=$ 7.0, 2.2 Hz, ArH, 1H), 7.65 (ddd, $J=8.5,4.5,2.2 \mathrm{~Hz}, \mathrm{ArH}, 1 \mathrm{H}), 7.19$ (t, $J=8.6 \mathrm{~Hz}, \mathrm{ArH}, 1 \mathrm{H}), 6.97(\mathrm{br} \mathrm{s}, 1 \mathrm{H}), 3.53\left(\mathrm{~d}, J=4.5 \mathrm{~Hz}, \mathrm{~N}-\mathrm{CH}_{2}, 2 \mathrm{H}\right)$, $2.28\left(\mathrm{~s}, \mathrm{~N}-\mathrm{CH}_{3}, 6 \mathrm{H}\right), 1.71-1.01\left(\mathrm{~m}, \mathrm{CH}_{2}, 10 \mathrm{H}\right) ;{ }^{13} \mathrm{C}$ NMR $(100$ $\left.\mathrm{MHz}, \mathrm{CDCl}_{3}\right): \delta$ (in ppm) 164.9, $159.6\left(\mathrm{~d},{ }^{1} J_{\mathrm{CF}}=-259 \mathrm{~Hz}\right), 131.9(\mathrm{~d}$, $\left.{ }^{4} J_{\mathrm{CF}}=3.6 \mathrm{~Hz}\right), 129.7,126.8\left(\mathrm{~d},{ }^{3} J_{\mathrm{CF}}=8.1 \mathrm{~Hz}\right), 121.2\left(\mathrm{~d},{ }^{2} J_{\mathrm{CF}}=17.4 \mathrm{~Hz}\right)$, $116.3\left(\mathrm{~d},{ }^{2} J_{\mathrm{CF}}=21.6 \mathrm{~Hz}\right), 77.1,57.6,40.7,37.6,28.3,26.0,22.4 ;{ }^{19} \mathrm{~F}$ $\operatorname{NMR}\left(377 \mathrm{MHz}, \mathrm{CDCl}_{3}\right): \delta$ (in ppm) $-111.17(\mathrm{~s}, 1 \mathrm{~F})$; IR (KBr) $\nu$ (in $\mathrm{cm}^{-1}$ ): 3327 (N-H stretching), 3088, 2931, 2852, 2819, 2785, 1641, $1551,1495,1316,1249$; HR-MS (ESI) $m / z$ : calcd for $\mathrm{C}_{16} \mathrm{H}_{22} \mathrm{ClFN}_{2} \mathrm{O}$, 312.1405; found, $313.1490(\mathrm{M}+\mathrm{H})^{+}$; HPLC by UV (254); >98\%.

4-Fluoro- $N$-\{[1-(dimethylamino)cyclohexyl]methyl\}benzamide (3c). Off-white solid (79.4\%), $R_{\mathrm{f}}=0.20\left(\mathrm{EtOAc}-\right.$ hexanes- $\mathrm{Et}_{3} \mathrm{~N}$; 40:55:5); ${ }^{1} \mathrm{H}$ NMR (400 MHz, CDCl3): $\delta$ (in ppm) 7.84-7.75 (m, ArH, 2H), 7.13-7.06 (m, ArH, 2H), $6.95(\mathrm{br} \mathrm{s}, 1 \mathrm{H}), 3.53(\mathrm{~d}, J=4.6 \mathrm{~Hz}$, $\left.\mathrm{N}-\mathrm{CH}_{2}, 2 \mathrm{H}\right), 2.28\left(\mathrm{~s}, \mathrm{~N}-\mathrm{CH}_{3}, 6 \mathrm{H}\right), 1.70-1.06\left(\mathrm{~m}, \mathrm{CH}_{2}, 10 \mathrm{H}\right) ;{ }^{13} \mathrm{C}$ NMR $\left(100 \mathrm{MHz}, \mathrm{CDCl}_{3}\right): \delta$ (in ppm) 166.4, $164.8\left(\mathrm{~d},{ }^{1} J_{\mathrm{CF}}=-250\right.$ $\mathrm{Hz}), 131.2\left(\mathrm{~d},{ }^{4} J_{\mathrm{CF}}=3 \mathrm{~Hz}\right), 129.3\left(\mathrm{~d},{ }^{3} J_{\mathrm{CF}}=8.8 \mathrm{~Hz}\right), 115.5\left(\mathrm{~d},{ }^{2} J_{\mathrm{CF}}=\right.$ $21.7 \mathrm{~Hz}), 57.7,40.6,37.6,28.3,26.0,22.5 ;{ }^{19} \mathrm{~F}$ NMR $(377 \mathrm{MHz}$, $\left.\mathrm{CDCl}_{3}\right): \delta$ (in ppm) $-108.97(\mathrm{~s}, 1 \mathrm{~F}), \mathrm{IR}(\mathrm{KBr}) \nu\left(\right.$ in cm $\left.^{-1}\right): 3318(\mathrm{~N}-$ $\mathrm{H}$ stretching), 2984, 2942, 2853, 2820, 2783, 1632, 1594, 1556, 1454, $1374,1348,1233$, 1161; HR-MS (ESI) $m / z$ : calcd for $\mathrm{C}_{16} \mathrm{H}_{23} \mathrm{FN}_{2} \mathrm{O}$, 278.1794; found, $279.1870(\mathrm{M}+\mathrm{H})^{+}$; HPLC by UV (254); >97\%.

4-(Trifluoromethyl)-N-\{[1-(dimethylamino)cyclohexyl]methyl\}benzamide (3d). Pale yellow solid $(72.3 \%), R_{\mathrm{f}}=0.27$ (EtOAchexanes- $\left.\mathrm{Et}_{3} \mathrm{~N} ; 40: 55: 5\right) ;{ }^{1} \mathrm{H}$ NMR (400 MHz, $\left.\mathrm{CDCl}_{3}\right): \delta$ (in ppm) $7.82(\mathrm{~d}, J=8.0 \mathrm{~Hz}, \mathrm{ArH}, 2 \mathrm{H}), 7.62(\mathrm{~d}, J=8.0 \mathrm{~Hz}, \mathrm{ArH}, 2 \mathrm{H}), 7.02$ (br s, $1 \mathrm{H}), 3.49\left(\mathrm{~d}, J=4.4 \mathrm{~Hz}, \mathrm{~N}-\mathrm{CH}_{2}, 2 \mathrm{H}\right), 2.22\left(\mathrm{~s}, \mathrm{~N}-\mathrm{CH}_{3}, 6 \mathrm{H}\right), 1.67-$ $1.01\left(\mathrm{~m}, \mathrm{CH}_{2}, 10 \mathrm{H}\right) ;{ }^{13} \mathrm{C} \mathrm{NMR}\left(100 \mathrm{MHz}, \mathrm{CDCl}_{3}\right): \delta$ (in ppm) 166.2, $138.4,133.1\left(\mathrm{q},{ }^{2} J_{\mathrm{CF}}=32 \mathrm{~Hz}\right), 127.5,125.6\left(\mathrm{q},{ }^{3} J_{\mathrm{C}_{-} \mathrm{CF}_{3}}=3.8 \mathrm{~Hz}\right), 124.0$ $\left(\mathrm{d},{ }^{1} J_{\mathrm{CF}}=-270 \mathrm{~Hz}\right), 57.7,40.7,37.6,28.3,26.0,22.5 ;{ }^{19} \mathrm{~F}$ NMR (377 $\left.\mathrm{MHz}, \mathrm{CDCl}_{3}\right): \delta$ (in ppm) -62.94 (s, 3F); IR (KBr) $\nu\left(\right.$ in cm$\left.^{-1}\right): 3259$, 2981, 2926, 2847, 1639, 1560, 1459, 1428, 1335, 1238, 1163, 1120, 1072; HR-MS (+ESI) $m / z$ : calcd for $\mathrm{C}_{17} \mathrm{H}_{23} \mathrm{~F}_{3} \mathrm{~N}_{2} \mathrm{O}$, 328.1762; found, $329.1833(\mathrm{M}+\mathrm{H})^{+}$; HPLC by UV (254); $98 \%$.

4-Fluoro-3-(trifluoromethyl)-N-\{[1-(dimethylamino)cyclohexyl]methyl\}benzamide (3e). Pale yellow solid (59.3\%), $R_{\mathrm{f}}=0.21$ (EtOAchexanes- $\left.\mathrm{Et}_{3} \mathrm{~N} ; 40: 55: 5\right) ;{ }^{1} \mathrm{H} \mathrm{NMR}\left(400 \mathrm{MHz}, \mathrm{CDCl}_{3}\right.$ ): $\delta$ (in ppm) 
8.07 (dd, $J=6.8,2.0 \mathrm{~Hz}, \mathrm{ArH}, 1 \mathrm{H}), 7.94$ (ddd, $J=8.1,4.6,2.3 \mathrm{~Hz}, \mathrm{ArH}$, $1 \mathrm{H}), 7.26(\mathrm{t}, J=9.2 \mathrm{~Hz}, \mathrm{ArH}, 2 \mathrm{H}), 7.02(\mathrm{br} \mathrm{s}, 1 \mathrm{H}), 3.55(\mathrm{~d}, J=4.5 \mathrm{~Hz}$, $\left.\mathrm{N}-\mathrm{CH}_{2}, 2 \mathrm{H}\right), 2.29\left(\mathrm{~s}, \mathrm{~N}-\mathrm{CH}_{3}, 6 \mathrm{H}\right), 1.74-1.33\left(\mathrm{~m}, \mathrm{CH}_{2}, 10 \mathrm{H}\right) ;{ }^{13} \mathrm{C}$ NMR $\left(100 \mathrm{MHz}, \mathrm{CDCl}_{3}\right): \delta$ (in ppm) 165.1, $161.4\left(\mathrm{~d},{ }^{1} J_{\mathrm{CF}}=-261\right.$ $\mathrm{Hz}), 132.6\left(\mathrm{~d},{ }^{3} J_{\mathrm{C}-\mathrm{CF}_{3}}=9 \mathrm{~Hz}\right), 131.4\left(\mathrm{~d},{ }^{4} J_{\mathrm{CF}}=4 \mathrm{~Hz}\right), 126.8(\mathrm{~m}), 122.3$ $\left(\mathrm{d},{ }^{1} J_{\mathrm{CF}-\mathrm{CF}_{3}}=-272 \mathrm{~Hz}\right), 118.7\left(\mathrm{dd},{ }^{2} J_{\mathrm{CF}}=33\right.$ and $\left.13 \mathrm{~Hz}\right), 117.2\left(\mathrm{~d},{ }^{2} J_{\mathrm{CF}}\right.$ $=21 \mathrm{~Hz}), 57.7,40.7,37.6,28.2,26.0,22.4 ;{ }^{19} \mathrm{~F}$ NMR $(377 \mathrm{MHz}$, $\left.\mathrm{CDCl}_{3}\right): \delta$ (in ppm) $-110.38\left(\mathrm{q}, J_{\mathrm{F}-\mathrm{CF}_{3}}=12.7 \mathrm{~Hz}, 1 \mathrm{~F}\right),-61.57(\mathrm{~d}$, $\left.J_{\mathrm{CF}_{3}-\mathrm{F}}=12.7 \mathrm{~Hz}, 3 \mathrm{~F}\right)$; IR $(\mathrm{KBr}) \nu\left(\right.$ in $\left.\mathrm{cm}^{-1}\right): 3328(\mathrm{~N}-\mathrm{H}$ stretching $)$, 3076, 2987, 2934, 2855, 2788, 1645, 1556, 1507, 1455, 1421; HR-MS (ESI) $m / z$ : calcd for $\mathrm{C}_{17} \mathrm{H}_{22} \mathrm{~F}_{4} \mathrm{~N}_{2} \mathrm{O}$, 346.1668; found, $347.1756(\mathrm{M}+$ $\mathrm{H})^{+}$; HPLC by UV $(254)$; $>98 \%$.

3-Fluoro-4-(trifluoromethyl)- $N$-\{[1-(dimethylamino)cyclohexyl]methyl\}benzamide (3f). Pale yellow solid $(58.6 \%), R_{\mathrm{f}}=0.27$ (EtOAchexanes- $\left.\mathrm{Et}_{3} \mathrm{~N} ; 40: 55: 5\right) ;{ }^{1} \mathrm{H} \mathrm{NMR}\left(400 \mathrm{MHz}, \mathrm{CDCl}_{3}\right): \delta$ (in ppm) 8.07 (dd, $J=6.8,2.0 \mathrm{~Hz}, \mathrm{ArH}, 1 \mathrm{H}), 7.94$ (ddd, $J=8.1,4.6,2.3 \mathrm{~Hz}, \mathrm{ArH}$, $1 \mathrm{H}), 7.26(\mathrm{t}, J=9.2 \mathrm{~Hz}, \mathrm{ArH}, 2 \mathrm{H}), 7.02(\mathrm{br} \mathrm{s}, 1 \mathrm{H}), 3.55(\mathrm{~d}, J=4.5 \mathrm{~Hz}$, $\left.\mathrm{N}-\mathrm{CH}_{2}, 2 \mathrm{H}\right), 2.29\left(\mathrm{~s}, \mathrm{~N}-\mathrm{CH}_{3}, 6 \mathrm{H}\right), 1.74-1.33\left(\mathrm{~m}, \mathrm{CH}_{2}, 10 \mathrm{H}\right) ;{ }^{13} \mathrm{C}$ $\operatorname{NMR}\left(100 \mathrm{MHz}, \mathrm{CDCl}_{3}\right): \delta$ (in ppm) $165.1,161.4\left(\mathrm{~d},{ }^{1} J_{\mathrm{CF}}=-261\right.$ $\mathrm{Hz}), 132.6\left(\mathrm{~d},{ }^{3} J_{\mathrm{C}-\mathrm{CF}_{3}}=9 \mathrm{~Hz}\right), 131.4\left(\mathrm{~d},{ }^{4} J_{\mathrm{CF}}=4 \mathrm{~Hz}\right), 126.8(\mathrm{~m}), 122.3$ $\left(\mathrm{d},{ }^{1} J_{\mathrm{CF}-\mathrm{CF}_{3}}=-272 \mathrm{~Hz}\right), 118.7\left(\mathrm{dd},{ }^{2} J_{\mathrm{CF}}=33\right.$ and $\left.13 \mathrm{~Hz}\right), 117.2\left(\mathrm{~d},{ }^{2} J_{\mathrm{CF}}\right.$ $=21 \mathrm{~Hz}), 57.7,40.7,37.6,28.2,26.0,22.4 ;{ }^{19} \mathrm{~F}$ NMR $(377 \mathrm{MHz}$, $\left.\mathrm{CDCl}_{3}\right): \delta$ (in ppm) $-110.38\left(\mathrm{q}, J_{\mathrm{F}-\mathrm{CF}_{3}}=12.7 \mathrm{~Hz}, 1 \mathrm{~F}\right),-61.57(\mathrm{~d}$, $\left.J_{\mathrm{CF}_{3}-\mathrm{F}}=12.7 \mathrm{~Hz}, 3 \mathrm{~F}\right)$; IR $(\mathrm{KBr}) \nu\left(\right.$ in cm $\left.{ }^{-1}\right): 3328(\mathrm{~N}-\mathrm{H}$ stretching $)$, 3076, 2987, 2934, 2855, 2788, 1645, 1556, 1507, 1455, 1421; HR-MS (+ESI) $m / z$ : calcd for $\mathrm{C}_{17} \mathrm{H}_{22} \mathrm{~F}_{4} \mathrm{~N}_{2} \mathrm{O}, 346.1668$; found, $347.1756(\mathrm{M}+$ $\mathrm{H})^{+}$; HPLC by UV $(254)$; >98\%.

3-(Trifluoromethyl)-N-\{[1-(dimethylamino)cyclohexyl]methyl\}-4methylbenzamide (3g). Off-white solid (64.8\%), $R_{\mathrm{f}}=0.26$ (EtOAchexanes- $\left.\mathrm{Et}_{3} \mathrm{~N} ; 40: 55: 5\right) ;{ }^{1} \mathrm{H} \mathrm{NMR}\left(400 \mathrm{MHz}, \mathrm{CDCl}_{3}\right): \delta$ (in ppm) $8.04(\mathrm{~s}, \mathrm{ArH}, 1 \mathrm{H}), 7.79(\mathrm{~d}, J=7.8 \mathrm{~Hz}, \mathrm{ArH}, 1 \mathrm{H}), 7.35(\mathrm{~d}, J=7.9 \mathrm{~Hz}$, $\mathrm{ArH}, 1 \mathrm{H}), 7.02(\mathrm{br} \mathrm{s}, 1 \mathrm{H}), 3.54\left(\mathrm{~d}, J=4.6 \mathrm{~Hz}, \mathrm{~N}-\mathrm{CH}_{2}, 2 \mathrm{H}\right), 2.52(\mathrm{~s}$, $\left.\mathrm{ArCH}_{3}, 3 \mathrm{H}\right), 2.28\left(\mathrm{~s}, \mathrm{~N}-\mathrm{CH}_{3}, 6 \mathrm{H}\right), 1.70-1.06\left(\mathrm{~m}, \mathrm{CH}_{2}, 10 \mathrm{H}\right) ;{ }^{13} \mathrm{C}$ $\operatorname{NMR}\left(100 \mathrm{MHz}, \mathrm{CDCl}_{3}\right): \delta$ (in ppm) $166.2,140.1,132.9,132.2,129.9$, $129.1\left(\mathrm{t},{ }^{1} J_{\mathrm{CF}}=30 \mathrm{~Hz}\right), 124.9\left(\mathrm{q},{ }^{3} J_{\mathrm{CF}}=5.7 \mathrm{~Hz}\right), 57.6,40.6,37.6,28.3$, 26.0, 22.5, 19.5; ${ }^{19} \mathrm{~F}$ NMR $\left(377 \mathrm{MHz}, \mathrm{CDCl}_{3}\right): \delta$ (in ppm) -61.90 (S, 3F); IR ( $\mathrm{KBr}) \nu\left(\right.$ in cm $\left.\mathrm{cm}^{-1}\right): 3251$ ( $\mathrm{N}-\mathrm{H}$ stretching), 3089, 2942, 2852, $2825,2784,1645,1555,1502,1455,1429,1424$; HR-MS (ESI) $\mathrm{m} / z$ : calcd for $\mathrm{C}_{18} \mathrm{H}_{25} \mathrm{~F}_{3} \mathrm{~N}_{2} \mathrm{O}$, 342.1919; found, $343.2005(\mathrm{M}+\mathrm{H})^{+}$; HPLC by UV (254); >98\%.

3,5-Bis(trifluoromethyl)- $N$-\{[1-(dimethylamino)cyclohexyl]methyl\}benzamide (3h). Pale yellow solid $(68.8 \%), R_{\mathrm{f}}=0.39$ (EtOAc-hexanes-Et $\left.{ }_{3} \mathrm{~N} ; 40: 55: 5\right),{ }^{1} \mathrm{H}$ NMR $\left(400 \mathrm{MHz}, \mathrm{CDCl}_{3}\right): \delta$ (in ppm) 8.19 (s, ArH, 2H), 7.98 (s, ArH, 1H), 7.19 (br s, 1H), 3.57 (d, $\left.J=4.4 \mathrm{~Hz}, \mathrm{~N}-\mathrm{CH}_{2}, 2 \mathrm{H}\right), 2.29\left(\mathrm{~s}, \mathrm{~N}-\mathrm{CH}_{3}, 6 \mathrm{H}\right), 1.72-1.07\left(\mathrm{~m}, \mathrm{CH}_{2}\right.$, $10 \mathrm{H}) ;{ }^{13} \mathrm{C}$ NMR $\left(100 \mathrm{MHz}, \mathrm{CDCl}_{3}\right): \delta$ (in ppm) 164.6, 137.2, 132.3 $\left(\mathrm{q},{ }^{2} J_{\mathrm{CF}}=34 \mathrm{~Hz}\right), 127.4,124.8\left(\mathrm{p},{ }^{3} J_{\mathrm{CF}}=4 \mathrm{~Hz}\right), 124.4,121.7,57.7,40.9$, $37.6,28.2,26.0,22.5 ;{ }^{19} \mathrm{~F} \mathrm{NMR}\left(377 \mathrm{MHz}, \mathrm{CDCl}_{3}\right): \delta$ (in ppm) -62.90 (s, 6F); IR (KBr) $\nu$ (in cm $\left.\mathrm{cm}^{-1}\right): 3322$ (N-H stretching), 3098, 2934, 2854, 2822, 2780, 1643, 1561, 1456, 1370, 1331, 1283, 1184; HR-MS (ESI) $\mathrm{m} / z$ : calcd for $\mathrm{C}_{18} \mathrm{H}_{22} \mathrm{~F}_{6} \mathrm{~N}_{2} \mathrm{O}, 396.1636$; found, $397.1701(\mathrm{M}+$ $\mathrm{H})^{+}$; HPLC by UV (254); >98\%.

$\mathrm{N}$-\{[1-(Dimethylamino)cyclohexyl]methyl\}-4-(trifluoromethoxy)benzamide (3i). Off-white solid (57.4\%). $R_{\mathrm{f}}=0.26$ (EtOAc-hexanes$\left.\mathrm{Et}_{3} \mathrm{~N} ; 40: 55: 5\right) ;{ }^{1} \mathrm{H}$ NMR $(400 \mathrm{MHz}, \mathrm{CDCl} 3): \delta$ (in ppm) 7.86-7.78 (m, ArH, 2H), 7.26 (d, J = 8.1 Hz, ArH, 2H), 7.03 (br s, 1H), 3.54 (d, $J$ $\left.=4.6 \mathrm{~Hz}, \mathrm{~N}-\mathrm{CH}_{2}, 2 \mathrm{H}\right), 2.27\left(\mathrm{~s}, \mathrm{~N}-\mathrm{CH}_{3}, 6 \mathrm{H}\right), 1.70-1.06\left(\mathrm{~m}, \mathrm{CH}_{2}\right.$, $10 \mathrm{H}) ;{ }^{13} \mathrm{C} \mathrm{NMR}\left(100 \mathrm{MHz}, \mathrm{CDCl}_{3}\right): \delta$ (in ppm) $166.2,151.3,133.5$, 128.9, $121.0\left(\mathrm{~d},{ }^{1} J_{\mathrm{CF}}=-259 \mathrm{~Hz}\right), 120.7,57.7,40.6,37.6,28.2,26.0$, 22.4; ${ }^{19} \mathrm{~F} \mathrm{NMR}\left(377 \mathrm{MHz}, \mathrm{CDCl}_{3}\right): \delta$ (in ppm) -57.7 (s, 3F); IR $(\mathrm{KBr}) \nu$ (in $\left.\mathrm{cm}^{-1}\right): 3261$ (N-H stretching), 3095, 2926, 2857, 2826, 2786, 1636, 1559, 1506, 1460, 1431, 1307, 1217, 1109; HR-MS (ESI) $m / z$ : calcd for $\mathrm{C}_{17} \mathrm{H}_{23} \mathrm{~F}_{3} \mathrm{~N}_{2} \mathrm{O}_{2}, 344.1712$; found, $345.1690(\mathrm{M}+\mathrm{H})^{+}$; HPLC by UV (254); $>98 \%$.

$\mathrm{N}$-\{[1-(Dimethylamino)cyclohexyl]methyl\}-4-methoxybenzamide (3j). Colorless solid (73\%), $R_{\mathrm{f}}=0.23\left(\mathrm{EtOAc}-\mathrm{hexanes}-\mathrm{Et}_{3} \mathrm{~N}\right.$; 40:55:5); ${ }^{1} \mathrm{H}$ NMR (400 MHz, $\mathrm{CDCl}_{3}$ ): $\delta$ (in ppm) 7.78-7.72 (m, $\mathrm{ArH}, 2 \mathrm{H}), 6.94-6.89(\mathrm{~m}, \mathrm{ArH}, 2 \mathrm{H}), 3.84\left(\mathrm{~s}, \mathrm{O}-\mathrm{CH}_{3}, 3 \mathrm{H}\right), 3.53(\mathrm{~d}, J=$ $\left.4.6 \mathrm{~Hz}, \mathrm{~N}-\mathrm{CH}_{2}, 2 \mathrm{H}\right), 2.28\left(\mathrm{~s}, \mathrm{~N}-\mathrm{CH}_{3}, 6 \mathrm{H}\right), 1.67-1.09\left(\mathrm{~m}, \mathrm{CH}_{2}\right.$, $10 \mathrm{H}) ;{ }^{13} \mathrm{C} \mathrm{NMR}\left(100 \mathrm{MHz}, \mathrm{CDCl}_{3}\right): \delta$ (in ppm) 167.0, 162.0, 128.8, $127.4,113.7,57.7,55.5,40.5,37.6,28.3,26.1,22.4$; IR (KBr) $\nu$ (in $\left.\mathrm{cm}^{-1}\right): 3360$ (N-H stretching), 2930, 2851, 2776, 1640, 1607, 1555, 1510, 1457; HR-MS (ESI): $m / z$ : calcd for $\mathrm{C}_{17} \mathrm{H}_{28} \mathrm{~N}_{2} \mathrm{O}_{2}, 290.1994$; found, $291.2074(\mathrm{M}+\mathrm{H})^{+}$; HPLC by UV $(254) ;>91 \%$.

3-Chloro-N-\{[1-(dimethylamino)cyclohexyl]methyl\}-4-nitrobenzamide ( $3 k$ ). Yellow solid $(63.6 \%), R_{\mathrm{f}}=0.20$ (EtOAc-hexanes-Et ${ }_{3} \mathrm{~N}$; 40:55:5); ${ }^{1} \mathrm{H}$ NMR $\left(400 \mathrm{MHz}, \mathrm{CDCl}_{3}\right): \delta$ (in ppm) $7.96(\mathrm{~d}, J=1.5 \mathrm{~Hz}$, $\mathrm{ArH}, 1 \mathrm{H}), 7.94-7.89(\mathrm{~m}, \mathrm{ArH}, 1 \mathrm{H}), 7.76(\mathrm{dd}, J=8.3,1.4 \mathrm{~Hz}, \mathrm{ArH}$, $1 \mathrm{H}), 7.15$ (br s, $1 \mathrm{H}), 3.55\left(\mathrm{~d}, J=4.4 \mathrm{~Hz}, \mathrm{~N}-\mathrm{CH}_{2}, 2 \mathrm{H}\right), 2.28(\mathrm{~s}, \mathrm{~N}-$ $\left.\mathrm{CH}_{3}, 6 \mathrm{H}\right), 1.70-1.09\left(\mathrm{~m}, \mathrm{CH}_{2}, 10 \mathrm{H}\right) ;{ }^{13} \mathrm{C} \mathrm{NMR}\left(100 \mathrm{MHz}, \mathrm{CDCl}_{3}\right): \delta$ (in ppm) 163.9, 149.1, 139.2, 130.6, 127.3, 125.8, 125.4, 57.4, 40.6, 37.3, 27.9, 25.6, 22.2; IR (KBr) $\nu$ (in cm $\left.{ }^{-1}\right): 3384$ (N-H stretching), 3084, 3000, 2934, 2865, 2798, 1669, 1545, 1500, 1478, 1377, 1290; HR-MS (ESI) $m / z$ : calcd for $\mathrm{C}_{16} \mathrm{H}_{22} \mathrm{ClN}_{3} \mathrm{O}_{3}, 339.1350$; found, $340.1435(\mathrm{M}+\mathrm{H})^{+}$; HPLC by UV (254); >98\%.

3-(Trifluoromethyl)-N-\{[1-(dimethylamino)cyclohexyl]methyl\}-4nitro-benzamide (3I). Yellow solid $(56.3 \%), R_{\mathrm{f}}=0.25$ (EtOAchexanes- $\mathrm{Et}_{3} \mathrm{~N}$; 40:55:5); ${ }^{1} \mathrm{H}$ NMR (400 MHz, $\mathrm{CDCl}_{3}$ ): $\delta$ (in ppm) $8.26-8.25(\mathrm{~m}, \mathrm{ArH}, 1 \mathrm{H}), 8.05$ (dd, $J=8.3,1.8 \mathrm{~Hz}, \mathrm{ArH}, 1 \mathrm{H}), 7.94-$ $7.91(\mathrm{~m}, \mathrm{ArH}, 1 \mathrm{H}), 7.24$ (br s, $1 \mathrm{H}), 3.57\left(\mathrm{~d}, J=4.3 \mathrm{~Hz}, \mathrm{~N}-\mathrm{CH}_{2}, 2 \mathrm{H}\right)$, $2.29\left(\mathrm{~s}, \mathrm{~N}-\mathrm{CH}_{3}, 6 \mathrm{H}\right), 1.72-1.08\left(\mathrm{~m}, \mathrm{CH}_{2}, 10 \mathrm{H}\right) ;{ }^{13} \mathrm{C} \mathrm{NMR}(100$ $\mathrm{MHz}, \mathrm{CDCl}_{3}$ ): $\delta$ (in ppm) 164.0, 139.1, 131.4, $127.4\left(\mathrm{q},{ }^{3} J_{\mathrm{CF}}=5 \mathrm{~Hz}\right.$ ), 125.4, $124.0\left(\mathrm{t},{ }^{1} \mathrm{~J}_{\mathrm{C}_{-} \mathrm{CF}_{3}}=34 \mathrm{~Hz}\right), 120.0,57.7,40.9,37.6,28.2,25.9$, $22.5 ;{ }^{19} \mathrm{~F} \mathrm{NMR}\left(283 \mathrm{MHz}, \mathrm{CDCl}_{3}\right): \delta$ (in ppm) -60.1 (s, 3F); IR $(\mathrm{KBr}) \nu\left(\right.$ in $\left.^{-1}\right): 3372(\mathrm{~N}-\mathrm{H}$ stretching $), 3079,3010,2938,2858$, 2804, 1672, 1539, 1494, 1463, 1366, 1288; HR-MS (ESI) $\mathrm{m} / z$ : calcd for $\mathrm{C}_{17} \mathrm{H}_{22} \mathrm{~F}_{3} \mathrm{~N}_{3} \mathrm{O}_{3}, 373.3762$; found, $374.3815(\mathrm{M}+\mathrm{H})^{+}$; HPLC by UV (254); >98\%.

General Procedure for the Preparation of Compounds $4 a-d$ and $5 a$ by $\mathrm{N}$-alkylation. $\mathrm{N}$-alkylation of benzamides was achieved as follows: To a solution of $3 \mathbf{a}-\mathbf{d}(0.3 \mathrm{mmol})$ in dry dimethylformamide, DMF (3 mL), sodium hydride, $\mathrm{NaH}(21.6 \mathrm{mg}, 0.9 \mathrm{mmol})$, was added, and the reaction mixture was allowed to stir for $30 \mathrm{~min}$ until the liberation of hydrogen ceased. Methyl iodide or 2-fluoroethyl tosylate (for $5 \mathrm{a}$ ) (0.6 mmol, 2 equiv) dissolved in $1 \mathrm{~mL}$ of DMF was added dropwise, and the mixture was stirred for $4 \mathrm{~h}$ at room temperature. Excess DMF was evaporated, and the residue was treated with aqueous $\mathrm{NH}_{4} \mathrm{OH}(30 \%$ in water, $10 \mathrm{~mL})$. The crude product was extracted with $\mathrm{Et}_{2} \mathrm{O}(3 \times 15 \mathrm{~mL})$ and purified by silica gel column chromatography using EtOAc-hexane-Et ${ }_{3} \mathrm{~N}, 30: 65: 0.5$.

3,4-Dichloro- $N$-\{[1-(dimethylamino)cyclohexyl]methyl\}-N-methylbenzamide (4a). Colorless solid $(56.2 \%), R_{f}=0.41$ (EtOAchexanes- $\mathrm{Et}_{3} \mathrm{~N}$; 40:55:5); ${ }^{1} \mathrm{H} \mathrm{NMR}\left(400 \mathrm{MHz}, \mathrm{CDCl}_{3}\right): \delta$ (in ppm) $7.51-7.46(\mathrm{~m}, \mathrm{ArH}, 2 \mathrm{H}), 7.24(\mathrm{dd}, J=8.3,1.9 \mathrm{~Hz}, \operatorname{ArH}, 1 \mathrm{H}), 3.56(\mathrm{~s}$, $\left.\mathrm{N}-\mathrm{CH}_{2}, 2 \mathrm{H}\right), 3.02\left(\mathrm{~s}, \mathrm{RC}(\mathrm{O}) \mathrm{N}-\mathrm{CH}_{3}, 3 \mathrm{H}\right), 2.36\left(\mathrm{~s}, \mathrm{~N}-\mathrm{CH}_{3}, 6 \mathrm{H}\right)$, $1.90-1.13\left(\mathrm{~m}, \mathrm{CH}_{2}, 10 \mathrm{H}\right) ;{ }^{13} \mathrm{C}$ NMR $\left(100 \mathrm{MHz} \mathrm{CDCl}_{3}\right): \delta$ (in ppm) 170.2, 137.0, 133.8, 132.9, 130.6, 129.1, 126.4, 77.4, 77.3, 77.1, 76.8, 59.6, 50.3, 41.7, 37.4, 32.7, 26.1, 21.2; IR ( $\mathrm{KBr}) \nu\left(\right.$ in $\left.\mathrm{cm}^{-1}\right): 2942$, 2851, 2817, 2774, 1642, 1591, 1459, 1430, 1377, 1336, 1276, 1197; HR-MS (ESI) $m / z$ : calcd for $\mathrm{C}_{17} \mathrm{H}_{24} \mathrm{Cl}_{2} \mathrm{~N}_{2} \mathrm{O}, 342.1266$; found, $343.1349(\mathrm{M}+\mathrm{H})^{+}$; HPLC by UV $(254)$; >97\%.

3-Chloro- $N$-\{[1-(dimethylamino) cyclohexyl]methyl\}-4-fluoro- $N$ methylbenzamide $(\mathbf{4 b})$. Colorless solid $(61.7 \%), R_{\mathrm{f}}=0.41$ (EtOAchexanes-Et ${ }_{3} \mathrm{~N}$; 40:55:0.5); ${ }^{1} \mathrm{H} \mathrm{NMR}(400 \mathrm{MHz}, \mathrm{CDCl} 3): \delta$ (in ppm) $7.47(\mathrm{dd}, J=7.0,2.0 \mathrm{~Hz}, \mathrm{ArH}, 1 \mathrm{H}), 7.30$ (ddd, $J=8.1,4.5,1.9 \mathrm{~Hz}, \mathrm{ArH}$, $1 \mathrm{H}), 7.17(\mathrm{t}, J=8.6 \mathrm{~Hz}, \mathrm{ArH}, 1 \mathrm{H}), 3.56\left(\mathrm{~s}, \mathrm{~N}-\mathrm{CH}_{2}, 2 \mathrm{H}\right), 3.03(\mathrm{~s}$, $\left.\mathrm{RC}(\mathrm{O}) \mathrm{N}-\mathrm{CH}_{3}, 3 \mathrm{H}\right), 2.36\left(\mathrm{~s}, \mathrm{~N}-\mathrm{CH}_{3}, 6 \mathrm{H}\right), 1.86-1.24\left(\mathrm{~m}, \mathrm{CH}_{2}\right.$, $10 \mathrm{H}) ;{ }^{13} \mathrm{CNMR}\left(100 \mathrm{MHz}, \mathrm{CDCl}_{3}\right): \delta$ (in ppm) $170.3,158.7\left(\mathrm{~d},{ }^{1} J_{\mathrm{CF}}=\right.$ $-251 \mathrm{~Hz}), 134.2\left(\mathrm{~d},{ }^{4} J_{\mathrm{CF}}=3.6 \mathrm{~Hz}\right), 129.8,127.3\left(\mathrm{~d},{ }^{3} J_{\mathrm{CF}}=8 \mathrm{~Hz}\right), 121.4$ $\left(\mathrm{d},{ }^{2} J_{\mathrm{CF}}=18 \mathrm{~Hz}\right), 116.7\left(\mathrm{~d},{ }^{2} J_{\mathrm{CF}}=21 \mathrm{~Hz}\right), 59.6,50.4,41.8,37.4,32.8$, 26.2, 21.2; $\left.{ }^{19} \mathrm{~F} \mathrm{NMR} \mathrm{(377} \mathrm{MHz,} \mathrm{CDCl}_{3}\right): \delta$ (in ppm) $-113.17(\mathrm{~s}, 1 \mathrm{~F})$; IR $(\mathrm{KBr}) \nu\left(\right.$ in cm $\left.^{-1}\right): 2945,2904,2855,2768,1649,1499,1474,1430$, 1392, 1335, 1275, 1149; HR-MS (ESI) $m / z$ : calcd for $\mathrm{C}_{17} \mathrm{H}_{24} \mathrm{ClFN}_{2} \mathrm{O}$, 326.1561; found, $327.1631(\mathrm{M}+\mathrm{H})^{+}$; HPLC by UV $(254)$; >97\%.

$\mathrm{N}$-\{[1-(Dimethylamino)cyclohexyl]methyl\}-4-fluoro-N-methylbenzamide (4c). Colorless solid (73\%), $R_{\mathrm{f}}=0.53$ (EtOAc-hexanes$\left.\mathrm{Et}_{3} \mathrm{~N} ; 40: 55: 5\right) ;{ }^{1} \mathrm{H} \mathrm{NMR}\left(400 \mathrm{MHz}, \mathrm{CDCl}_{3}\right): \delta$ (in ppm) 7.44-7.40 (m, ArH, 2H), 7.11-7.06 (m, ArH, 2H), $3.58\left(\mathrm{~s}, \mathrm{~N}-\mathrm{CH}_{2}, 2 \mathrm{H}\right), 3.03$ (s, 
$\left.\mathrm{RC}(\mathrm{O}) \mathrm{N}-\mathrm{CH}_{3}, 3 \mathrm{H}\right), 2.36\left(\mathrm{~s}, \mathrm{~N}-\mathrm{CH}_{3}, 6 \mathrm{H}\right), 1.92-1.27\left(\mathrm{~m}, \mathrm{CH}_{2}\right.$, $10 \mathrm{H}) ;{ }^{13} \mathrm{C} \mathrm{NMR}\left(100 \mathrm{MHz}, \mathrm{CDCl}_{3}\right): \delta$ (in ppm) $171.8,163.4\left(\mathrm{~d},{ }^{1} J_{\mathrm{CF}}=\right.$ $-250 \mathrm{~Hz}), 133.2\left(\mathrm{~d},{ }^{4} J_{\mathrm{CF}}=3.6 \mathrm{~Hz}\right), 129.3\left(\mathrm{~d},{ }^{3} J_{\mathrm{CF}}=8 \mathrm{~Hz}\right), 115.5(\mathrm{~d}$, $\left.{ }^{2} J_{\mathrm{CF}}=22 \mathrm{~Hz}\right), 59.6,50.3,42.0,37.4,32.8,26.2,21.2 ;{ }^{19} \mathrm{~F}$ NMR (377 $\left.\mathrm{MHz}, \mathrm{CDCl}_{3}\right): \delta$ (in ppm) $-110.74(\mathrm{~s}, 1 \mathrm{~F})$; IR $(\mathrm{KBr}) \nu\left(\right.$ in $\left.\mathrm{cm}^{-1}\right)$ : 2933, 2907, 2847, 2775, 1607, 1513, 1466, 1429, 1395, 1337, 1286, 1196; HR-MS (+ESI) $m / z$ : calcd for $\mathrm{C}_{17} \mathrm{H}_{25} \mathrm{FN}_{2} \mathrm{O}, 292.1951$; found, 293.2022 $(\mathrm{M}+\mathrm{H})^{+}$; HPLC by UV $(254)$; $>98 \%$.

$N-\{[1$-(Dimethylamino) cyclohexyl]methyl $\}-N$-methyl-4(trifluoromethyl)benzamide (4d). Off-white solid (76.3\%), $R_{\mathrm{f}}=0.48$ (EtOAc-hexanes-Et $\left.{ }_{3} \mathrm{~N} ; 40: 55: 5\right) ;{ }^{1} \mathrm{H}$ NMR (400 MHz, CDCl3): $\delta$ (in ppm) $7.67(\mathrm{~d}, J=8.1 \mathrm{~Hz}, \mathrm{ArH}, 2 \mathrm{H}), 7.51(\mathrm{~d}, J=8.0 \mathrm{~Hz}, \mathrm{ArH}, 2 \mathrm{H})$, $3.59\left(\mathrm{~s}, \mathrm{~N}-\mathrm{CH}_{2}, 2 \mathrm{H}\right), 3.00\left(\mathrm{~s}, \mathrm{RC}(\mathrm{O}) \mathrm{N}-\mathrm{CH}_{3}, 3 \mathrm{H}\right), 2.37\left(\mathrm{~s}, \mathrm{~N}-\mathrm{CH}_{3}\right.$, $6 \mathrm{H}), 1.95-1.25\left(\mathrm{~m}, \mathrm{CH}_{2}, 10 \mathrm{H}\right) ;{ }^{13} \mathrm{C} \mathrm{NMR}\left(100 \mathrm{MHz}, \mathrm{CDCl}_{3}\right): \delta$ (in ppm) $171.2,140.8,131.5\left(\mathrm{q},{ }^{2} J_{\mathrm{CF}}=32 \mathrm{~Hz}\right), 127.3,125.6(\mathrm{~m}), 123.9(\mathrm{~d}$, $\left.{ }^{1} J_{\mathrm{CF}}=-270 \mathrm{~Hz}\right), 59.6,50.2,41.6,37.4,32.8,26.2,21.2 ;{ }^{19} \mathrm{~F} \operatorname{NMR}(377$ $\left.\mathrm{MHz}, \mathrm{CDCl}_{3}\right): \delta$ (in ppm) $-62.84(\mathrm{~s}, 3 \mathrm{~F})$; IR $(\mathrm{KBr}) \nu\left(\right.$ in cm $\left.^{-1}\right): 3064$, 2936, 2852, 2821, 2780, 1630, 1577, 1461, 1431, 1376, 1284, 1184, 1131, 1080; HR-MS (ESI) $m / z$ : calcd for $\mathrm{C}_{18} \mathrm{H}_{25} \mathrm{~F}_{3} \mathrm{~N}_{2} \mathrm{O}$, 342.1919; found, $343.1993(\mathrm{M}+\mathrm{H})^{+}$; HPLC by UV $(254)$; >98\%.

3,4-Dichloro- $N$-\{[1-(dimethylamino) cyclohexyl]methyl\}-N-(2fluoroethyl)benzamide (5a). Yellow oil (21.3\%), $R_{\mathrm{f}}=0.33($ EtOAchexanes- $\left.\mathrm{Et}_{3} \mathrm{~N} ; 40: 55: 5\right) ;{ }^{1} \mathrm{H} \mathrm{NMR}\left(400 \mathrm{MHz}, \mathrm{CDCl}_{3}\right): \delta$ (in ppm) $7.52-7.47(\mathrm{~m}, \mathrm{ArH}, 2 \mathrm{H}), 7.22(\mathrm{dd}, J=8.2,1.8 \mathrm{~Hz}, \mathrm{ArH}, 1 \mathrm{H}), 4.69(\mathrm{dt}, J$ $\left.=4.1 \mathrm{~Hz}, J_{\mathrm{HF}}=48 \mathrm{~Hz}, \mathrm{~F}-\mathrm{CH}_{2}, 2 \mathrm{H}\right), 4.40\left(\mathrm{dt}, J=4.1 \mathrm{~Hz}, J_{\mathrm{HF}}=21 \mathrm{~Hz}\right.$, $1 \mathrm{H}), 2.28\left(\mathrm{~s}, \mathrm{~N}-\mathrm{CH}_{3}, 6 \mathrm{H}\right), 1.68-1.20\left(\mathrm{~m}, \mathrm{CH}_{2}, 10 \mathrm{H}\right) ;{ }^{13} \mathrm{C} \mathrm{NMR}(100$ $\mathrm{MHz}, \mathrm{CDCl}_{3}$ ): $\delta$ (in ppm) 156.3, 134.0, 132.9, 131.6, 130.4, 130.3, $127.5,81.8\left(\mathrm{~d},{ }^{1} J_{\mathrm{CF}}=169 \mathrm{~Hz}\right), 64.6\left(\mathrm{~d},{ }^{2} J_{\mathrm{CF}}=20 \mathrm{~Hz}\right), 57.9,51.5,38.1$, 32.4, 26.2, 21.5; IR (KBr) $\nu\left(\right.$ in cm $\left.^{-1}\right): 2931,2854,2820,2779,1667$, $1590,1467,1379,1281,1245$; HR-MS (ESI) $m / z$ : calcd for $\mathrm{C}_{18} \mathrm{H}_{25} \mathrm{Cl}_{2} \mathrm{FN}_{2} \mathrm{O}$, 374.1328; found, $375.1409(\mathrm{M}+\mathrm{H})^{+}$; HPLC by UV (254); >97\%.

Synthesis of tert-Butyl(1-cyanocyclohex-1-yl-N-methyl)carbamate. To 1-(methylamino) cyclohexane-1-carbonitrile ( $0.5 \mathrm{~g}$, $3.6 \mathrm{mmol})$ in DCM $(2.5 \mathrm{~mL})$ was added $\mathrm{Boc}_{2} \mathrm{O}(2.36 \mathrm{~g}, 10.8 \mathrm{mmol})$ and left to stir for 5 days until NMR confirmed complete consumption of the starting material. The majority of solvents were removed under reduced pressure $\left(50 \mathrm{mbar}, 40^{\circ} \mathrm{C}, 1 \mathrm{~h}\right)$, and the crude product was purified via flash column chromatography using 0-20\% EtOAc in hexanes to yield tert-butyl(1-cyanocyclohex-1-yl- $N$-methyl)carbamate as white solids in $90 \%(774 \mathrm{mg}, 3.24 \mathrm{mmol}) .{ }^{1} \mathrm{H}$ NMR $(400 \mathrm{MHz}$, $\left.\mathrm{CDCl}_{3}\right): \delta$ (in ppm) $2.92\left(\mathrm{~s}, \mathrm{~N}-\mathrm{CH}_{3}, 3 \mathrm{H}\right), 2.39-2.30\left(\mathrm{~m}, \mathrm{CH}_{2}, 2 \mathrm{H}\right)$, 1.85-1.62 (m, CH, $8 \mathrm{H}), 1.51\left(\mathrm{~s}, \mathrm{C}\left(\mathrm{CH}_{3}\right)_{3}, 9 \mathrm{H}\right)$. MS (ESI): 261.157 $[\mathrm{M}+\mathrm{Na}]^{+}$. HR-MS (ESI): $m / z$ : calcd for $\mathrm{C}_{13} \mathrm{H}_{22} \mathrm{~N}_{2} \mathrm{NaO}_{2}{ }^{+}, 261.1573$, found $261.1574[\mathrm{M}+\mathrm{Na}]^{+}$.

tert-Butyl(1-\{[4-fluoro-3-(trifluoromethyl)benzamido]methyl\}cyclohexyl)(methyl)carbamate. Orange oil, $41 \%$ yield ( $88 \mathrm{mg}, 0.20$ mmol). ${ }^{1} \mathrm{H} \mathrm{NMR} \mathrm{(400} \mathrm{MHz,} \mathrm{CDCl}_{3}$ ): $\delta$ (in ppm) 8.49 (s, ArH, $1 \mathrm{H}$ ), $8.18(\mathrm{dd}, J=6.8,2.3 \mathrm{~Hz}, \mathrm{ArH}, 1 \mathrm{H}), 8.11$ (ddd, $J=8.6,4.7,2.3 \mathrm{~Hz}, \mathrm{ArH}$, $1 \mathrm{H}), 7.22(\mathrm{~d}, J=9.2 \mathrm{~Hz}, 1 \mathrm{H}), 3.50\left(\mathrm{~d}, J=4.1 \mathrm{~Hz}, \mathrm{~N}-\mathrm{CH}_{2}, 2 \mathrm{H}\right), 2.86(\mathrm{~s}$, $\left.\mathrm{N}-\mathrm{CH}_{3}, 3 \mathrm{H}\right), 2.62-2.34\left(\mathrm{~m}, \mathrm{CH}_{2}, 2 \mathrm{H}\right), 1.70-1.58\left(\mathrm{~m}, \mathrm{CH}_{2}, 3 \mathrm{H}\right), 1.57$ $\left(\mathrm{s}, \mathrm{CH}_{2}, 1 \mathrm{H}\right), 1.50\left(\mathrm{~d}, J=12.1 \mathrm{~Hz}, \mathrm{CH}_{2}, 2 \mathrm{H}\right), 1.45\left(\mathrm{~s}, \mathrm{C}\left(\mathrm{CH}_{3}\right)_{3}, 9 \mathrm{H}\right)$, $1.37\left(\mathrm{~d}, J=8.3 \mathrm{~Hz}, \mathrm{CH}_{2}, 3 \mathrm{H}\right) .{ }^{13} \mathrm{C}$ NMR $\left(100 \mathrm{MHz}, \mathrm{CDCl}_{3}\right): \delta$ (in ppm) $164.9,158.6,133.0\left(\mathrm{~d}, J^{3}=9 \mathrm{~Hz}\right), 130.7\left(\mathrm{~d}, J^{3}=4 \mathrm{~Hz}\right), 126.5(\mathrm{q}, J$ $=2 \mathrm{~Hz}), 117.0\left(\mathrm{~d}, J^{2}=21 \mathrm{~Hz}\right), 80.4,59.5,48.7,33.9,31.3,28.3,25.7$, 22.0. ${ }^{19} \mathrm{~F}$ NMR $\left(376 \mathrm{MHz}, \mathrm{CDCl}_{3}\right): \delta$ (in ppm) $-61.55(\mathrm{~d}, J=12.8$ $\mathrm{Hz}),-110.35(\mathrm{q}, J=12.8 \mathrm{~Hz})$. MS (ESI): $m / z: 455.193[\mathrm{M}+\mathrm{Na}]^{+}$. HR-MS (ESI, MeOH) $m / z$ : calcd for $\mathrm{C}_{21} \mathrm{H}_{28} \mathrm{~F}_{4} \mathrm{~N}_{2} \mathrm{O}_{3}{ }^{+}, 455.1928$, found $455.1928[\mathrm{M}+\mathrm{Na}]^{+}$.

3-Trifluoromethyl-4-fluoro- $N-\{[1-($ methylamino)cyclohex-1-yl]methyl\}benzamide. To tert-butyl (1-\{[4-fluoro-2-(trifluoromethyl)benzamido]methyl $\}$ cyclohexyl) (methyl)carbamate (44 mg, 0.10 $\mathrm{mmol})$ dissolved in DCM $(5 \mathrm{~mL})$, TFA $(0.4 \mathrm{~mL})$ was added dropwise over $5 \mathrm{~min}$. After $30 \mathrm{~min}$, the mixture was concentrated to dryness. The residue was taken up in $\mathrm{K}_{2} \mathrm{CO}_{3}$ and extracted with EtOAc $(3 \times 15 \mathrm{~mL})$ at $\mathrm{pH} 12-14$. The combined organic portions were washed with brine, dried over $\mathrm{Na}_{2} \mathrm{SO}_{4}$, and then evaporated to dryness to afford a yield of $73 \%(24.8 \mathrm{mg}, 0.07 \mathrm{mmol})$ as an orange oil. ${ }^{1} \mathrm{H}$ NMR $(400 \mathrm{MHz}$, $\mathrm{CDCl}_{3}$ ): $\delta$ (in ppm) 8.07 (dd, $\left.J=6.8,2.3 \mathrm{~Hz}, \mathrm{ArH}, 1 \mathrm{H}\right), 7.97$ (ddd, $J=$ 8.6, 4.7, 2.3 Hz, ArH, 1H), 7.23 (d, J = 9.2 Hz, ArH, 1H), 7.03 (s, NH,
$1 \mathrm{H}), 3.33\left(\mathrm{~d}, J=4.7 \mathrm{~Hz}, \mathrm{~N}-\mathrm{CH}_{2}, 2 \mathrm{H}\right), 2.27\left(\mathrm{~s}, \mathrm{~N}-\mathrm{CH}_{3}, 3 \mathrm{H}\right), 1.53(\mathrm{dd}$, $\left.J=9.5,3.4 \mathrm{~Hz}, \mathrm{CH}_{2}, 5 \mathrm{H}\right), 1.42\left(\mathrm{dd}, J=8.9,4.5 \mathrm{~Hz}, \mathrm{CH}_{2}, 5 \mathrm{H}\right) .{ }^{13} \mathrm{C} \mathrm{NMR}$ $\left(100 \mathrm{MHz}_{1} \mathrm{CDCl}_{3}\right): \delta\left(\right.$ in ppm) $165.2(\mathrm{~s}), 161.5\left(\mathrm{dq}, J_{\mathrm{C}-\mathrm{F}}{ }^{1}=260 \mathrm{~Hz}, J\right.$ $=2 \mathrm{~Hz}), 132.8\left(\mathrm{~d}, J_{\mathrm{C}-\mathrm{F}}{ }^{3}=9 \mathrm{~Hz}\right), 131.5\left(\mathrm{~d}, J^{4}=4 \mathrm{~Hz}\right), 126.8\left(\mathrm{dq}, J^{3}=5\right.$ $\left.\mathrm{Hz}, J^{3}=2 \mathrm{~Hz}\right), 122.3\left(\mathrm{dq}, J_{\mathrm{C}-\mathrm{F}_{3}}{ }^{1}=272 \mathrm{~Hz}, J=1 \mathrm{~Hz}\right), 118.8\left(\mathrm{dq}, J^{2}=34\right.$ $\left.\mathrm{Hz}, J^{2}=15 \mathrm{~Hz}\right), 117.2\left(\mathrm{~d}, J_{\mathrm{C}-\mathrm{F}}{ }^{2}=20 \mathrm{~Hz}\right), 53.7(\mathrm{~s}), 44.3(\mathrm{~s}), 33.3(\mathrm{~s})$, $27.3(\mathrm{~s}), 25.9(\mathrm{~s}), 21.7(\mathrm{~s}) .{ }^{19} \mathrm{~F} \mathrm{NMR}\left(376 \mathrm{MHz}, \mathrm{CDCl}_{3}\right): \delta$ (in ppm) $-61.55(\mathrm{~d}, J=12.8 \mathrm{~Hz}),-110.35(\mathrm{q}, J=12.8 \mathrm{~Hz})$. MS $(\mathrm{ESI}): \mathrm{m} / z$ : $333.158[\mathrm{M}+\mathrm{H}]^{+}$. HR-MS (ESI) $m / z$ : calcd for $\mathrm{C}_{16} \mathrm{H}_{21} \mathrm{~F}_{4} \mathrm{~N}_{2} \mathrm{O}^{+}$, 333.1585 , found $333.1585[\mathrm{M}+\mathrm{H}]^{+}$. HPLC by UV $(254) ;>95 \%$.

tert-Butyl\{1-[(3-chloro-4-fluorobenzamido)methyl]cyclohex-1yl\}methyl)carbamate. It was obtained as a colorless solid in $17 \%$ yield $(52.1 \mathrm{mg}, 0.13 \mathrm{mmol}) .{ }^{1} \mathrm{H}$ NMR (400 MHz, $\left.\mathrm{CDCl}_{3}\right): \delta$ (in ppm) 8.25 (s, ArH, 1H), 7.95 (dd, J = 7.0, 2.2 Hz, ArH, 1H), 7.77 (ddd, $J=8.6,4.5$, $2.2 \mathrm{~Hz}, \mathrm{ArH}, 1 \mathrm{H}), 7.15(\mathrm{t}, J=8.6 \mathrm{~Hz}, \mathrm{NH}, 1 \mathrm{H}), 3.48(\mathrm{~d}, J=4.2 \mathrm{~Hz}, \mathrm{~N}-$ $\left.\mathrm{CH}_{2}, 2 \mathrm{H}\right)$ (methanol), $2.84\left(\mathrm{~s}, \mathrm{~N}-\mathrm{CH}_{3}, 3 \mathrm{H}\right), 2.54-2.43\left(\mathrm{~m}, \mathrm{CH}_{2}\right.$, $2 \mathrm{H}), 1.65-1.55\left(\mathrm{~m}, \mathrm{CH}_{2}, 3 \mathrm{H}\right), 1.46\left(\mathrm{~s}, \mathrm{C}\left(\mathrm{CH}_{3}\right)_{3}, 9 \mathrm{H}\right), 1.44-1.29(\mathrm{~m}$, $\left.\mathrm{CH}_{2}, 7 \mathrm{H}\right) .{ }^{13} \mathrm{C}$ NMR $\left(100 \mathrm{MHz}, \mathrm{CDCl}_{3}\right): \delta$ (in ppm) $165.3,160.1$ (d, $\left.J^{1}=254 \mathrm{~Hz}\right), 131.6\left(\mathrm{~d}, J^{3}=4 \mathrm{~Hz}\right), 130.07,127.5\left(\mathrm{~d}, J^{3}=8 \mathrm{~Hz}\right), 121.5(\mathrm{~d}$, $\left.J^{2}=18 \mathrm{~Hz}\right), 116.6\left(\mathrm{~d}, J^{2}=22 \mathrm{~Hz}\right), 80.45,59.73,48.78$ (methanol), $34.17,31.42,28.62,28.58,28.54,25.87,22.09 .{ }^{19} \mathrm{~F}$ NMR $(376 \mathrm{MHz}$ $\left.\mathrm{CDCl}_{3}\right): \delta$ (in ppm) -111.41. MS (ESI): $m / z: 421.166[\mathrm{M}+\mathrm{Na}]^{+}$. HR-MS (ESI) $m / z$ : calcd for $\mathrm{C}_{20} \mathrm{H}_{28} \mathrm{ClFN}_{2} \mathrm{NaO}_{3}{ }^{+}, 421.1665$, found $421.1665[\mathrm{M}+\mathrm{Na}]^{+}$.

3-Chloro-4-fluoro-N-\{[1-(methylamino)cyclohex-1-yl]methyl\}benzamide. It was obtained as an orange oil in $41 \%$ yield $(16 \mathrm{mg}, 0.05$ mmol). ${ }^{1} \mathrm{H} \mathrm{NMR}\left(400 \mathrm{MHz}, \mathrm{CDCl}_{3}\right): \delta$ (in ppm) 8.01 (dd, $J=7.0,2.3$ $\mathrm{Hz}, \mathrm{ArH}, 1 \mathrm{H}), 7.82$ (ddd, $J=8.6,4.5,2.3 \mathrm{~Hz}, \mathrm{ArH}, 1 \mathrm{H}), 7.41$ (s, ArH, $1 \mathrm{H}), 7.16(\mathrm{t}, J=8.6 \mathrm{~Hz}, \mathrm{NH}, 1 \mathrm{H}), 3.54\left(\mathrm{~d}, J=5.2 \mathrm{~Hz}, \mathrm{~N}-\mathrm{CH}_{2}, 2 \mathrm{H}\right)$, $2.42\left(\mathrm{~s}, \mathrm{~N}-\mathrm{CH}_{3}, 3 \mathrm{H}\right), 1.61\left(\mathrm{~d}, J=6.1 \mathrm{~Hz}, \mathrm{CH}_{2}, 4 \mathrm{H}\right), 1.55(\mathrm{dq}, J=9.4$, 5.3, $\left.4.7 \mathrm{~Hz}, \mathrm{CH}_{2}, 4 \mathrm{H}\right), 1.45\left(\mathrm{~s}, \mathrm{CH}_{2}, 2 \mathrm{H}\right) .{ }^{13} \mathrm{C} \mathrm{NMR}(101 \mathrm{MHz}$, $\left.\mathrm{CDCl}_{3}\right): \delta\left(\right.$ in ppm) $165.7(\mathrm{~s}), 160.1\left(\mathrm{~d}, J_{\mathrm{C}-\mathrm{F}}{ }^{1}=254 \mathrm{~Hz}\right), 131.5\left(\mathrm{~d}, J^{3}=\right.$ $4 \mathrm{~Hz}), 130.46(\mathrm{~s}), 127.6\left(\mathrm{~d}, J^{3}=8 \mathrm{~Hz}\right), 121.6\left(\mathrm{~d}, J^{2}=18 \mathrm{~Hz}\right), 116.7(\mathrm{~d}$, $\left.J^{2}=22 \mathrm{~Hz}\right), 57.1,42.7,32.2,26.8,25.4,21.6 .{ }^{19} \mathrm{~F}$ NMR $(376 \mathrm{MHz}$, $\left.\mathrm{CDCl}_{3}\right): \delta$ (in ppm) -110.77 . MS (ESI, $\left.\mathrm{MeOH}\right) \mathrm{m} / z: 299.132$. HRMS (ESI) $m / z$ : calcd for $\mathrm{C}_{15} \mathrm{H}_{21} \mathrm{ClFN}_{2} \mathrm{O}^{+}, 299.1321$, found 299.1321 $[\mathrm{M}+\mathrm{H}]^{+}$. HPLC by UV $(254) ;>95 \%$.

Lipophilicity $\left(\log D_{7.4}\right)^{27}$ The determination of $\log D_{7.4}$ values was performed by HPLC analysis based on two calibration curves, which were conducted from 27 reference compounds with known $\log P$ values and correlation of measured $\log k^{\prime}$ values to the known $\log P$ values. The first calibration curve was determined for reference compounds with log $P$ values in the range $0-4.0$, using a Chromolith endcapped RP-18e $(100 \times 4.6 \mathrm{~mm})$ as a stationary phase and methanol-phosphate buffer $(50 \mathrm{mM}, \mathrm{pH} 7.4)(1: 1, \mathrm{v} / \mathrm{v})$ as a mobile phase with a flow rate of $1 \mathrm{~mL} /$ min. The second calibration curve was determined for reference compounds with $\log P$ values in the range 4.0-5.5, using a Chromolith endcapped RP-18 $(100 \times 4.6 \mathrm{~mm})$ and $\mathrm{MeOH}-$ phosphate buffer $(50$ $\mathrm{mM}, \mathrm{pH} 7.4)(3: 1, \mathrm{v} / \mathrm{v})$ as a mobile phase with a flow rate of $2 \mathrm{~mL} / \mathrm{min}$. The mean retention time of each reference compound $(10 \mu \mathrm{g} / \mathrm{mL}$ in methanol/water 3:1) was analyzed in triplicate by HPLC. The linear correlation between the capacity factor $(\log k)$ and $\log P$ values $\left(R^{2}=\right.$ 0.9 ) was used to calculate $\log D_{7.4}$ values from the HPLC analysis of test compounds $3 \mathrm{a}-1$.

In Vitro OR Binding Studies. Affinities of the test compounds toward the human ORs DOR, KOR, and $\mu \mathrm{OR}$, were determined as described previously. ${ }^{18,19,28}$ In brief, competition binding experiments were performed with membranes from HEK293T cells transiently transfected with the receptor of interest using the Mirus TransIT-293 transfection reagent (Peqlab, Erlangen, Germany) or a solution of linear polyethyleneimine in phosphate-buffered saline (PBS), as described previously. ${ }^{18,19,23}$ Binding affinities were determined using the radioligand $\left[{ }^{3} \mathrm{H}\right]$ diprenorphine (Biotrend, Cologne, Germany) at concentrations of $0.3 \mathrm{nM}$ (DOR and KOR) and $0.2-0.3 \mathrm{nM}$ (MOR) and homogenates at 3-14 $\mu \mathrm{g} /$ well protein (DOR), 4-5 $\mu \mathrm{g} /$ well (KOR), and 2-10 $\mu \mathrm{g} /$ well (MOR). Binding properties of the homogenates were determined with $K_{\mathrm{d}}(\mathrm{DOR})=0.15 \pm 0 \mathrm{nM}, K_{\mathrm{d}}$ $($ KOR $)=0.067 \pm 0.003 \mathrm{nM}$, and $K_{\mathrm{d}}($ MOR $)=0.072 \pm 0.011 \mathrm{nM}$ and $B_{\max }(\mathrm{DOR})=2600 \pm 980 \mathrm{fmol} / \mathrm{mg}, B_{\max }(\mathrm{KOR})=3000 \pm 0 \mathrm{fmol} / \mathrm{mg}$, and $B_{\max }(\mathrm{MOR})=2500 \pm 570 \mathrm{fmol} / \mathrm{mg}$. Nonspecific binding was 
determined in the presence of naloxone $(10 \mu \mathrm{M}$ for DOR, KOR, and MOR). Protein concentration was established by the method of Lowry using bovine serum albumin as the standard. Data analysis of the competition binding curves from the radioligand displacement experiments was performed by nonlinear regression analysis when applying the algorithms of the program PRISM 6.0 (GraphPad, San Diego, CA, USA). $\mathrm{IC}_{50}$ values were derived from each competition binding curve and were transformed into the corresponding $K_{\mathrm{i}}$ values by applying the equation of Cheng and Prusoff. Mean $K_{\mathrm{i}}$ values are the results of two to four individual experiments, each performed in triplicate.

In Vitro OR Potency. Division-arrested $\mathrm{CHO}-\mathrm{K} 1$ cells stably expressing the $\mathrm{G}_{\mathrm{i} / \mathrm{o}}$-protein-coupled human delta, kappa, and mu ORs were obtained from Cambridge Bioscience (Cambridge, UK) and plated on 384 well plates. Test compounds were assayed for agonistmediated inhibition of intracellular cAMP response using the HitHunter cAMP kit (DiscoveRx). Eleven concentrations of each test compound were incubated in the presence of forskolin $(10 \mu \mathrm{M})$ and 3isobutyl-1-methylxanthine (IBMX, $0.5 \mathrm{mM}$ ) for $20 \mathrm{~min}$ at $37^{\circ} \mathrm{C}$. Intracellular cAMP levels were read out by measuring a betagalactosidase-dependent chemiluminescent signal. The reference agonists deltorphin (DOR), U50488 (KOR), and DAMGO (MOR) were included. The nonselective OR antagonist naloxone was included as a negative control. When a pronounced dose-dependent receptor activation was detected, the potency of the agonist $\left(\mathrm{EC}_{50} / \mathrm{nM}\right)$ was determined. Assays were run in quadruplicate (two independent duplicates) unless a variability $>2 \%$ was observed.

In Vitro Rat Brain AR. Competitive binding experiments were performed with both $3 \mathbf{b}$ and $3 \mathbf{e}$ against the antagonist radioligand $\left[{ }^{3} \mathrm{H}\right]$ naloxone $\left(A_{\mathrm{s}}=2.59 \mathrm{GBq} / \mu \mathrm{mol}, 70 \mathrm{Ci} / \mathrm{mmol}\right)$ and the agonist radioligand $\left[{ }^{3} \mathrm{H}\right]$ DAMGO $\left(A_{\mathrm{s}}=1.98 \mathrm{GBq} / \mu \mathrm{mol} ; 53.7 \mathrm{Ci} / \mathrm{mmol}\right)$ on rat brain tissue slices using AR. At the day before the preparation of brain slices, the frozen brains of Sprague-Dawley rats $(>400 \mathrm{~g})$ were taken out from $-80{ }^{\circ} \mathrm{C}$ and stored at $-20{ }^{\circ} \mathrm{C}$ overnight. Transaxial sections $(20 \mu \mathrm{m}$ thickness) were prepared using a Cryostar NX70 microtome (Fisher Scientific AS, Norway) and mounted on Superfrost slides (VWR AS, Oslo, Norway). The sections are stored at $-80{ }^{\circ} \mathrm{C}$ until the day of incubation. The sections were warmed to room temperature $\left(22{ }^{\circ} \mathrm{C}\right)$ to be used for $\left[{ }^{3} \mathrm{H}\right]$ DAMGO AR and preincubated in Tris buffer $(50 \mathrm{mM}, \mathrm{pH}=7.4)$ containing $\mathrm{NaCl}$ $(0.9 \%)$ for $30 \mathrm{~min}$ at room temperature $\left(22^{\circ} \mathrm{C}\right)$, while preincubation for $\left[{ }^{3} \mathrm{H}\right]$ naloxone AR sections was performed in PBS. The incubation with the radioligands $\left[{ }^{3} \mathrm{H}\right]$ DAMGO $(4 \mathrm{nM})$ and $\left[{ }^{3} \mathrm{H}\right]$ naloxone $(2 \mathrm{nM})$ was carried out in Tris $(50 \mathrm{mM}, \mathrm{pH}=7.4)$ and PBS $(25 \mathrm{mM}, \mathrm{pH}=7.4)$, respectively, in the presence of $3000,1000,300,100,30,10$, and $1 \mathrm{nM}$ of $3 \mathbf{b}$ and $3 \mathrm{e}$ for $60 \mathrm{~min}$ at $22{ }^{\circ} \mathrm{C}$. The nonspecific binding was determined at each concentration using diprenorphine $(1 \mu \mathrm{M})$. The sections were washed with ice cold buffers (Tris for $\left[{ }^{3} \mathrm{H}\right]$ DAMGO AR and $\mathrm{PBS}$ for $\left[{ }^{3} \mathrm{H}\right]$ naloxone AR) for $4 \mathrm{~min}(3 \times)$ following a rapid dip in ice cold deionized water. The sections were dried and exposed to a Fuji BAS TR imaging screen (GE Healthcare Norway AS, Oslo, Norway) for 4 weeks. The screen was analyzed by a high-resolution storage phosphor screen reader (Duerr CR-35 bio, Duerr GmbH, Germany). The inhibition of radioligand binding in three MOR-rich brain regions (thalamus, striatum, and presubiculum) was evaluated by drawing ROIs and quantification of radioactivity signal using AIDA image analysis software (Raytest GmbH, Straubenhardt, Germany). Manual thresholding was used to draw the regions on the first section. Initial regions were copied into the adjacent sections and adjusted according to the anatomy of the rat brain ROIs.

Radiosyntheses. Radiosynthesis of $\left[{ }^{18} \mathrm{~F}\right] 3 \mathrm{~b}$. In general, a typical batch of $5-10 \mathrm{GBq}\left[{ }^{18} \mathrm{~F}\right]$ fluoride ions was produced using the ${ }^{18} \mathrm{O}(\mathrm{p}, \mathrm{n}){ }^{18} \mathrm{~F}$ nuclear reaction via proton bombardment of an enriched $\mathrm{H}_{2}{ }^{18} \mathrm{O}$ liquid target on a GEHC PETtrace 800 cyclotron (NMS AS, Rikshospitalet, Oslo, Norge). The target water containing the $\left[{ }^{18} \mathrm{~F}\right]$ fluoride ion was passed through a Waters SepPak light QMA cartridge that was preconditioned with $1 \mathrm{M}$ potassium carbonate solution $(5 \mathrm{~mL})$ and water $(10 \mathrm{~mL})$. Potassium carbonate, $\mathrm{K}_{2} \mathrm{CO}_{3}(5$ $\mathrm{mg}, 0.036 \mathrm{mmol})$ in water $(200 \mu \mathrm{L})$, and crypt-222 $(10 \mathrm{mg}, 0.027$ mmol, 99\%) in acetonitrile $(400 \mu \mathrm{L})$ were used to elute the $\left[{ }^{18} \mathrm{~F}\right]$ fluoride ion from the cartridge into a V-bottomed reaction vessel. The vial was heated to $130{ }^{\circ} \mathrm{C}$ for $10 \mathrm{~min}$ under a stream of argon. Two cycles of addition evaporation of anhydrous $\mathrm{MeCN}(0.6 \mathrm{~mL})$ were performed with $5 \mathrm{~min}$ of heating in each cycle. The temperature was increased to $150{ }^{\circ} \mathrm{C}$, precursor $3 \mathrm{k}(3.5 \mathrm{mg}, 10 \mu \mathrm{mol})$ in anhydrous DMF $(0.6 \mathrm{~mL})$ was added, and labeling was performed at $150{ }^{\circ} \mathrm{C}$ for 8 min. The reaction mixture was diluted with $\mathrm{H}_{2} \mathrm{O}(3 \mathrm{~mL})$ and passed through the first $\mathrm{C} 18$ cartridge that was preconditioned with $\mathrm{EtOH}$ (5 $\mathrm{mL}) . \mathrm{C}_{18}$ was rinsed with $\mathrm{H}_{2} \mathrm{O}(5 \mathrm{~mL})$, and the retained product was eluted into a second vial using acetonitrile $(0.7 \mathrm{~mL})$. The product fraction was diluted with $0.7 \mathrm{~mL}$ of $\mathrm{KH}_{2} \mathrm{PO}_{4}(50 \mathrm{mM}, \mathrm{pH} 7)$, mixed well, and injected into the semipreparative HPLC equipped with a Luna c18(2) $(250 \times 10 \mathrm{~mm})$, and separation of $\left[{ }^{18} \mathrm{~F}\right] 3 \mathbf{b}$ from the reaction mixture was achieved using a mixture of $\mathrm{MeCN}-\mathrm{KH}_{2} \mathrm{PO}_{4}(50 \mathrm{mM}, \mathrm{pH}$ $7 ; 3: 7)$ at a flow rate of $8 \mathrm{~mL} / \mathrm{min}$. The HPLC fraction containing $\left[{ }^{18} \mathrm{~F}\right]$ $3 \mathbf{b}$ was collected in a $100 \mathrm{~mL}$ collection flask, diluted with water (50 $\mathrm{mL}$ ), and loaded on the second $\mathrm{c} 18$ to trap the product over it. Water $(10 \mathrm{~mL})$ was passed through the $\mathrm{C} 18$ afterward, and retained $\left[{ }^{18} \mathrm{~F}\right] 3 \mathrm{~b}$ was eluted with $\mathrm{Et}_{2} \mathrm{O}(0.7 \mathrm{~mL})$ into a glass vial. $\mathrm{Et}_{2} \mathrm{O}$ was dried under the stream of nitrogen at $40{ }^{\circ} \mathrm{C}$ for $3 \mathrm{~min}$, and the product was formulated with EtOH ( $>10 \%)$ in physiological saline ( $3 \mathrm{~mL}$ in total) followed by sterile filtering with a $0.22 \mu \mathrm{m}$ filter (Merck) in a noncorrected RCY of $21 \pm 5 \%(n=5)$ and radiochemical and chemical purity of $>97 \%$.

QC of $\left[{ }^{18} \mathrm{~F}\right] 3 \mathrm{~b}$. Radiochemical purity of $\left[{ }^{18} \mathrm{~F}\right] 3 \mathbf{b}$ was determined by a radio-TLC scanner (Raytest) using $\mathrm{SiO}_{2} \mathrm{~F} 254$ TLC plates as the stationary phase and EtOAc-hexanes- $\mathrm{Et}_{3} \mathrm{~N}(65: 30: 5)$ as the mobile phase. Chemical and radiochemical purity was analyzed on an analytical HPLC equipped with a Luna C18(2) $(250 \times 4.6 \mathrm{~mm})$ column using $\mathrm{MeCN}-\mathrm{KH}_{2} \mathrm{PO}_{4}(50 \mathrm{mM}, \mathrm{pH} 7 ; 2: 3)$ at a flow rate of $1.8 \mathrm{~mL} / \mathrm{min}$. The QC chromatograms of both radio-TLC and HPLC are shown in Figures $S 1$ and S2. Concentration and molar activity of the final product were determined by HPLC analysis of the formulated radiotracer considering the calibration curve of the reference samples with the known concentration $(\mathrm{nmol} / \mathrm{mL})$ and calculating the cold mass from the area of the UV peak corresponding to the retention time of the reference compound.

Stability of $\left[{ }^{18} \mathrm{~F}\right] 3 \mathrm{~b}$ in the Final Formulation. A sample $(2 \mu \mathrm{L})$ was spotted on silica gel $60 \mathrm{~F}_{254}$-coated aluminum TLC plates (Merck KgAA, Darmstadt, Germany) at 1,2,3,5, and $7 \mathrm{~h}$ to confirm the stability of $\left[{ }^{18} \mathrm{~F}\right] 3 \mathbf{b}$ in the final formulation using the radio-TLC procedure described above. It was observed that the product is stable for up to $7 \mathrm{~h}$ with a radiochemical purity of $>98 \%$. In order to support the TLC results and to check the chemical purity, $10 \mu \mathrm{L}$ of the sample was injected in HPLC at 1,3,5, and $7 \mathrm{~h}$ using a Phenomenex Luna C18 (2) column $(5 \mu \mathrm{m} ; 100 \AA ; 250 \mathrm{~mm} \times 4.6 \mathrm{~mm})$ and isocratic mixture of $\mathrm{MeCN}$-phosphate buffer $(0.1 \mathrm{M}, \mathrm{pH} 7 ; 30: 70)$ at a flow rate of 1.8 $\mathrm{mL} / \mathrm{min}$.

Radiosynthesis of $\left[{ }^{18} \mathrm{~F}\right] 3 \mathrm{e}$. Because high amounts of nonradioactive reference compound $3 \mathrm{e}(54 \mu \mathrm{g}, 157 \mathrm{nmol} / \mathrm{mL})$ were obtained when $\left[{ }^{18} \mathrm{~F}\right] 3 \mathbf{e}$ was synthesized using the conditions developed for radiosynthesis of $\left[{ }^{18} \mathrm{~F}\right] \mathbf{3 b}$, new radiolabeling conditions were developed for the synthesis of $\left[{ }^{18} \mathrm{~F}\right] 3 \mathbf{e}$ as follows. A batch of $5-10 \mathrm{GBq}\left[{ }^{18} \mathrm{~F}\right]$ fluoride was extracted from target water with crypt-222 $(10 \mathrm{mg}, 27 \mu \mathrm{mol})$ and $\mathrm{K}_{2} \mathrm{CO}_{3}(5 \mathrm{mg}, 36 \mu \mathrm{mol})$ in $\mathrm{MeCN}-\mathrm{H}_{2} \mathrm{O}(4: 1,0.6 \mathrm{~mL})$ and dried using two cycles of $\mathrm{MeCN}(0.6 \mathrm{~mL})$ at $130^{\circ} \mathrm{C}$ for a total time period of 20 $\min$. The temperature of the reactor was then decreased to $75^{\circ} \mathrm{C}$, and $\mathrm{NO}_{2}$-to- ${ }^{18} \mathrm{~F}$ substitution was achieved by the addition of 31 ( $3.5 \mathrm{mg}, 10$ $\mu \mathrm{mol})$ in anhydrous DMF $(0.6 \mathrm{~mL})$ at $75^{\circ} \mathrm{C}$ for $3 \mathrm{~min}$. The reaction mixture was diluted with $\mathrm{H}_{2} \mathrm{O}(3.5 \mathrm{~mL})$ and passed through the first $\mathrm{C}_{18}$ cartridge. The cartridge was rinsed with $\mathrm{H}_{2} \mathrm{O}(5 \mathrm{~mL})$, and the product $\left[{ }^{18} \mathrm{~F}\right] 3 \mathrm{e}$ was eluted into a second vial using acetonitrile $(0.7 \mathrm{~mL})$. The product fraction was then diluted with $0.7 \mathrm{~mL}$ of $\mathrm{NH}_{4} \mathrm{HCO}_{2}(0.1 \mathrm{M}$, $\mathrm{pH} 7$ ), mixed thoroughly, and injected into the semipreparative highperformance liquid chromatograph equipped with an HS-F5 column $(250 \times 10 \mathrm{~mm})$ using the $\mathrm{MeCN}-\mathrm{NH}_{4} \mathrm{HCO}_{2}(0.1 \mathrm{M}, \mathrm{pH} 7 ; 9: 1)$ mixture at an isocratic flow rate of $5 \mathrm{~mL} / \mathrm{min}$. The HPLC fraction containing $\left[{ }^{18} \mathrm{~F}\right] 3 \mathrm{e}$ was collected in a $100 \mathrm{~mL}$ collection flask and loaded on the second $\mathrm{C}_{18}$ cartridge after diluting with water $(50 \mathrm{~mL})$. $\mathrm{H}_{2} \mathrm{O}(10 \mathrm{~mL})$ was passed through the $\mathrm{C}_{18}$ afterward, and retained $\left[{ }^{18} \mathrm{~F}\right]$ 
$3 \mathbf{e}$ was eluted into a clean glass vial using $\mathrm{Et}_{2} \mathrm{O}(0.7 \mathrm{~mL})$. $\mathrm{Et}_{2} \mathrm{O}$ was dried under a stream of nitrogen at $40{ }^{\circ} \mathrm{C}$ for $3 \mathrm{~min}$, and the product was formulated with $\mathrm{EtOH}(>10 \%)$ in physiological saline $(2.0 \mathrm{~mL})$, followed by filtering with a $0.22 \mu \mathrm{m}$ filter in a noncorrected RCY of $23 \pm$ $4 \%(n=5)$ and a radiochemical and chemical purity of $>97 \%$.

QC of $\left[{ }^{18} \mathrm{~F}\right] 3$ e. Radiochemical purity of the formulated product was determined by radio-TLC using $\mathrm{SiO}_{2} \mathrm{~F}_{254}$ TLC plates as a stationary phase and EtOAc-hexanes- $\mathrm{Et}_{3} \mathrm{~N}$ (65:30:5) as a mobile phase. Chemical and radiochemical quantification was performed on an analytical high-performance liquid chromatograph equipped with HSF5 $(250 \times 4.6 \mathrm{~mm})$ using $\mathrm{MeCN}-\mathrm{NH}_{4} \mathrm{HCO}_{2}(9: 1 ; 0.1 \mathrm{M}, \mathrm{pH} 7)$ with a flow rate of $1.0 \mathrm{~mL} / \mathrm{min}$. The QC result of the final product is shown in Figure S12. The molar activity and the amount of substance in the final formulation were determined by HPLC using the calibration curve obtained after injecting the reference $3 \mathbf{e}$ with known concentrations $(\mathrm{nmol} / \mathrm{mL})$, as shown in Figure S13.

Stability of $\left[{ }^{18} \mathrm{~F}\right] 3 e$ in the Final Formulation. The stability of $\left[{ }^{18} \mathrm{~F}\right] 3 \mathrm{e}$ was determined by radio-TLC and radio-HPLC using the analytical conditions described above. The samples were taken from the final formulation and analyzed at $1,3,5$, and $7 \mathrm{~h}$ to determine the stability of $\left[{ }^{18} \mathrm{~F}\right] 3 \mathrm{e}$ at room temperature. See the Supporting Information.

HPLC analysis of the Desmethyl Analogue of $3 b$. Considering the reported metabolism of AH-7921 (3a), we assumed that the observed radioactive and more hydrophilic metabolites of $\left[{ }^{18} \mathrm{~F}\right] 3 \mathbf{b}$ in blood could be ascribed to demethylation. Therefore, we synthesized the desmethyl analogue of $\mathbf{3} \mathbf{b}$ and analyzed the compound by HPLC. Figure S19 shows the HPL chromatogram of a mixture of compound $\mathbf{3 b}$ (shown in green) and its desmethylated analogue (in red). The HPL chromatogram revealed that $\left[{ }^{18} \mathrm{~F}\right] \mathbf{3 b}$ and its desmethyl analogue have a very similar retention time.

In Vitro Stability. ${ }^{27}$ The stability of both $\left[{ }^{18} \mathrm{~F}\right] 3 \mathbf{b}$ and $\left[{ }^{18} \mathrm{~F}\right] 3 \mathbf{e}$ was determined in human serum (Li-Heparin; Merck Biochrom, Darmstadt) and rat plasma (Li-Heparin; collected from male SpragueDawley rat blood samples). An aliquot of the radiotracer (5-10 MBq) was added to $200 \mu \mathrm{L}$ of human serum or rat plasma and incubated at 37 ${ }^{\circ} \mathrm{C}$. Aliquots of $15 \mu \mathrm{L}$ were taken after $5,10,15,30,45,60,120$, and 180 min and quenched in aqueous TFA $(10 \%, 100 \mu \mathrm{L})$. The samples were centrifuged $(20,000 \mathrm{~g}, 2 \mathrm{~min})$, and the supernatants were analyzed by radio-HPLC (Chromolith performance RP-18e, $100 \times 4.6 \mathrm{~mm}$; flow rate: $4 \mathrm{~mL} / \mathrm{min}$; solvent $\mathrm{A}$ : water $(0.1 \% \mathrm{TFA})$; solvent $\mathrm{B}$ : acetonitrile (0.1\% TFA); gradient: $10-90 \% \mathrm{~B}$ in A in $8 \mathrm{~min}$ ).

Animal Experiments. All experiments were approved by the local animal protection authorities (Government of Central Franconia, Germany, no. 55.2 2532-2-618-14) and performed at the FAU in accordance with the relevant institutional guidelines and EU regulations. Ten to thirteen week-old female CD Sprague-Dawley rats (220-300 g; strain code: 001, Charles River) were used for animal experiments.

In Vivo Metabolism. The right femoral artery of two rats per radiotracer was cannulated to allow for arterial blood sampling. Blood samples $(150 \mu \mathrm{L})$ were taken at $2,5,10,30$, and $45 \mathrm{~min}$ p.i. of $\left[{ }^{18} \mathrm{~F}\right] 3 \mathbf{b}$ or $\left[{ }^{18} \mathrm{~F}\right]$ 3e. Samples were collected in Li-heparinized Microvettes $(100$ $\mathrm{LH}$, Sarstedt $)$ and centrifuged $(2000 \mathrm{~g}, 5 \mathrm{~min})$. Supernatant plasma (50 $\mu \mathrm{L}$ ) was quenched in $50 \mu \mathrm{L}$ of $10 \%$ aqueous TFA and centrifuged $(20,000 \mathrm{~g}, 5 \mathrm{~min})$. An aliquot $(10 \mu \mathrm{L})$ of the supernatant was analyzed in the $\gamma$-counter (Wallac Wizard), and $50 \mu \mathrm{L}$ of the supernatant from each radiotracer was analyzed by radio-HPLC using the Kromasil C8 column $(100 \AA ; 250 \times 4.6 \mathrm{~mm})$ in gradient elution; $20-53.3 \% \mathrm{MeCN}(0.1 \%$ TFA) in water (0.1\% TFA) for $25 \mathrm{~min}, 53.3-80 \% \mathrm{MeCN}(0.1 \% \mathrm{TFA})$ in water $(0.1 \%$ TFA) for $4 \mathrm{~min}, 80-100 \% \mathrm{MeCN}(0.1 \%$ TFA $)$ in water ( $0.1 \%$ TFA) for $1 \mathrm{~min}$, and ending to $100 \% \mathrm{MeCN}$ (0.1\% TFA) for 4 min. The HPLC eluate was collected in fractions of $1.5 \mathrm{~mL}$, and the fractions were analyzed in the $\gamma$-counter (Wallac Wizard). For each point of time, the percentage of the intact radiotracer was calculated as the sum of counts in fractions containing the intact radiotracer divided by the sum of counts in all fractions containing the metabolite or intact radiotracer. The function describing the amount of intact radiotracer was fitted using the "one-phase decay" model in GraphPad Prism. One rat per radiotracer was sacrificed by decapitation under isoflurane anesthesia, and the brain was harvested for metabolite studies. The cerebellum and cortex were separated from the rest of the brain, weighed, and analyzed in the $\gamma$-counter (Wallac Wizard). The three fractions were homogenized separately by grinding under $10 \%$ aqueous TFA $(3 \mathrm{~mL} / \mathrm{g}$ tissue) in a glass tissue homogenizer for $5 \mathrm{~min}$. The supernatant layer was transferred to a centrifuge tube, centrifuged $(20,000 \mathrm{~g}, 5 \mathrm{~min})$, and analyzed by radio-HPLC as described above for the blood samples.

Arterial Blood Sampling and Plasma Input Function. The right femoral artery of one rat per radiotracer was cannulated to allow for arterial blood sampling. Blood samples of $30 \mu \mathrm{L}$ were taken every $10 \mathrm{~s}$ for the first $2 \mathrm{~min}$ p.i. of $\left[{ }^{18} \mathrm{~F}\right] 3 \mathrm{~b}$ and $\left[{ }^{18} \mathrm{~F}\right] 3 \mathrm{e}$ at 150 and $180 \mathrm{~s}$ and then at $5,10,20,30,60$, and $90 \mathrm{~min}$. Samples were collected in Liheparinized Microvettes (100 LH, Sarstedt), centrifuged (2000g, 5 $\mathrm{min}$ ), weighed, and analyzed using a $\gamma$-counter (Wallac Wizard). An aliquot $(10 \mu \mathrm{L})$ of the supernatant plasma was transferred to a test tube and counted as a reference. Values were corrected for decay, calculated as $\% \mathrm{ID} / \mathrm{g}$, and corrected for metabolites by considering the graph describing the amount of intact radiotracer over time. The plasma input function was fitted using the "two-phase decay" model in GraphPad Prism.

Ex Vivo AR. Two rats per radiotracer were sacrificed at $45 \mathrm{~min}$ p.i. of $\left[{ }^{18} \mathrm{~F}\right] 3 \mathbf{b}$ and $\left[{ }^{18} \mathrm{~F}\right] \mathbf{3 e}$ by decapitation under isoflurane anesthesia, and the brain was excised and subsequently frozen in hexane/dry ice bath $\left(-70^{\circ} \mathrm{C}\right)$. Coronal rat brain slices $(14 \mu \mathrm{m})$ were prepared on a cryostat microtome (HM 500-O, Microm, Walldorf, Germany) and thawmounted on adhesive glass slides (Histobond, Marienfeld, LaudaKönigshofen, Germany). Slides were carefully dried in a stream of warm air and finally placed on a phosphor imaging plate (Fuji Imaging Plate BAS-IP SR 2025 E, Fujifilm, Düsseldorf) overnight prior to readout on the autoradiograph (HD-CR-35 Bio, Dürr NDT, Germany) and analysis with AIDA image analysis software (Elysia-raytest, Straubenhardt, Germany).

Histology. The brain tissue slices $(15 \mu \mathrm{m})$ for staining with hematoxylin/eosin (HE) were fixated in ice cold acetone for $20 \mathrm{~min}$. Slices were transferred to hematoxylin solution (modified according to Gill; Merck Millipore, Darmstadt) for $3 \mathrm{~min}$ and dipped in $0.1 \%$ aqueous $\mathrm{HCl}$ for $2 \mathrm{~s}$. Differentiation was performed in running water for 3 min followed by incubation in eosin-Y $(0.5 \%$, alcoholic; Merck Millipore) for $5 \mathrm{~min}$. Differentiation was again carried out in running water for $30 \mathrm{~s}$. Dehydration of slices was performed using an ascending series of ethanol $70 \%(\mathrm{v} / \mathrm{v})(2 \times 4 \mathrm{~s})$, ethanol $96 \%(\mathrm{v} / \mathrm{v})(2 \times 2 \mathrm{~min})$, and xylene $(2 \times 5 \mathrm{~min})$. Finally, slices were embedded in Entellan (Merck Millipore) and covered with glass slides.

In Vivo PET Imaging. Dynamic small-animal PET scans were performed on an Inveon microPET scanner (Siemens Healthcare, Erlangen, Germany). Female Sprague-Dawley rats (220-280 g, 1013 weeks of age) were intravenously injected into the tail vein with $\left[{ }^{18} \mathrm{~F}\right]$ $3 \mathbf{b}$ or $\left[{ }^{18} \mathrm{~F}\right] 3 \mathrm{e}(10-28 \mathrm{MBq})$ under isoflurane anesthesia $(4-5 \%)$. Depending on the parallel or subsequent experimental procedures, dynamic emission recordings were acquired at $0-120 \mathrm{~min}(n=1), 0-$ $90 \mathrm{~min}$ (including arterial blood sampling, $n=1$ ), or $0-45 \mathrm{~min}$ (including subsequent ex vivo $\mathrm{AR}$ and determination of radioactive metabolites in vivo, $n=2$ ). For displacement studies of $\left[{ }^{18} \mathrm{~F}\right] \mathbf{3 b}$, rats were coinjected with the radioligand and naloxone $(1 \mathrm{mg} / \mathrm{kg}, n=2)$. Dynamic emission images were corrected for decay and attenuation, and MAP (iterative maximum a posteriori) images were reconstructed using the built-in software of the PET scanner. The time frames for the image reconstruction were set to $0-120 \mathrm{~min}: 10 \times 12 \mathrm{~s}, 3 \times 60 \mathrm{~s}, 5 \times$ $300 \mathrm{~s}, 9 \times 600 \mathrm{~s} ; 0-90 \mathrm{~min}: 10 \times 12 \mathrm{~s}, 3 \times 60 \mathrm{~s}, 5 \times 300 \mathrm{~s}, 6 \times 600 \mathrm{~s}$; and $0-45 \mathrm{~min}: 12 \times 10 \mathrm{~s}, 3 \times 60 \mathrm{~s}, 8 \times 300 \mathrm{~s}$. Evaluation of the MAP images was conducted using the software Amide (A Medical Image Data Examiner, GNU General Public License, version 1.0.4) for visual control.

PET Image Data Analysis. The software PMOD 3.8 (Pmod Technologies LLC, Zurich, Switzerland) was used for PET data analysis. For each rat, early frames $(0-2 \mathrm{~min})$ were summed into static images. These images were warped into MNI space using nonlinear coregistration functions provided by the software combined with an FDG image. The transformation obtained was applied to the original, 
dynamic PET data set. After visual inspection, ROIs drawn on the MRI template were copied into the PET data. Time-activity curves were extracted for representative, large regions and used for kinetic analysis in conjunction with the metabolite-corrected plasma activity curves. Built-in kinetic models were applied to fit the time-activity curves based on either plasma or reference tissue (cerebellum) input and obtain quantitative measures of radiotracer kinetics.

\section{ASSOCIATED CONTENT}

\section{(s) Supporting Information}

The Supporting Information is available free of charge at https://pubs.acs.org/doi/10.1021/acs.jmedchem.0c00683.

Information on general experimental details, radiosyntheses and quality control of $\left[{ }^{18} \mathrm{~F}\right] 3 \mathbf{b}$ and $\left[{ }^{18} \mathrm{~F}\right] \mathbf{3 e}$, HPLC analysis of desmethyl-3b, NMR spectra of the title compounds, PET images, and modeling curves (PDF)

Receptor binding affinities of compounds $3 a-j$ and $4 a-d$ (CSV)

\section{AUTHOR INFORMATION}

\section{Corresponding Author}

Patrick J. Riss - Realomics SRI, Kjemisk Institutt, Universitetet $i$ Oslo, N-0376 Oslo, Norway; Division of Clinical Neuroscience, Neuroscience Research Unit, OUS-UllevÅl, N-0450 Oslo, Norway; $\odot$ orcid.org/0000-0002-3887-7065;

Email: patrick.riss@kjemi.uio.no

\section{Authors}

Julian Ott - Department of Nuclear Medicine, Molecular Imaging and Radiochemistry, Translational Research Center, Friedrich Alexander University Erlangen-Nürnberg (FAU), D-91054 Erlangen, Germany

Mona M. Spilhaug - Realomics SRI, Kjemisk Institutt, Universitetet i Oslo, N-0376 Oslo, Norway

Simone Maschauer - Department of Nuclear Medicine, Molecular Imaging and Radiochemistry, Translational Research Center, Friedrich Alexander University Erlangen-Nürnberg (FAU), D-91054 Erlangen, Germany; (c) orcid.org/00000002-6550-933X

Waqas Rafique - Realomics SRI, Kjemisk Institutt, Universitetet $i$ Oslo, N-0376 Oslo, Norway

Jimmy E. Jakobsson - Realomics SRI, Kjemisk Institutt, Universitetet i Oslo, N-0376 Oslo, Norway; (1) orcid.org/00000002-5266-0591

Karoline Hartvig - Realomics SRI, Kjemisk Institutt, Universitetet i Oslo, N-0376 Oslo, Norway

Harald Hübner - Department of Chemistry and Pharmacy, Medicinal Chemistry, Emil Fischer Center, Friedrich Alexander University Erlangen-Nürnberg (FAU), D-91058 Erlangen, Germany

Peter Gmeiner - Department of Chemistry and Pharmacy, Medicinal Chemistry, Emil Fischer Center, Friedrich Alexander University Erlangen-Nürnberg (FAU), D-91058 Erlangen, Germany; 이이이.org/0000-0002-4127-197X

Olaf Prante - Department of Nuclear Medicine, Molecular Imaging and Radiochemistry, Translational Research Center, Friedrich Alexander University Erlangen-Nürnberg (FAU), D91054 Erlangen, Germany; 이이. orcid/0000-0003-02473656

Complete contact information is available at: https://pubs.acs.org/10.1021/acs.jmedchem.0c00683

\section{Notes}

The authors declare no competing financial interest.

\section{ACKNOWLEDGMENTS}

Parts of this work have been previously published as a $\mathrm{PhD}$ thesis ${ }^{28}$ using the institutional repository and online publication system OPUS FAU. The initial publication on OPUS FAU does not legally preclude further publication of the document in journals or monographs and on other repositories. This study was funded by the faculty of Mathematics and Natural Sciences, University of Oslo, and the Department of Chemistry, University of Oslo (startup grant to P.J.R.). This work was supported by the Norwegian Research Council grant ES 231553 to P.J.R. This work was supported by the Deutsche Forschungsgemeinschaft within the framework of DFG Research Training Group "Medicinal Chemistry of Selective GPCR Ligands" (GRK 1910). The authors are grateful to Manuel Geisthoff, Department of Nuclear Medicine, FAU, for excellent technical support during animal experiments. The authors also thank A. T. Aalvik and E. M. Ivarson for production and delivery of ${ }^{18} \mathrm{~F}$.

\section{ABBREVIATIONS}

$\mathrm{AR}$, autoradiography; $\mathrm{BP}_{\mathrm{ND}}$, nondisplaceable binding potential; $\mathrm{CHO}$, Chinese hamster ovary; DAMGO, H-Tyr-D-Ala-Gly- $N$ MePhe-Gly-ol; DOR, $\delta$-opioid receptor; EOB, end of bombardment; GPCR, G-protein-coupled receptor; HEK, human embryonic kidney; KOR, $\kappa$-opioid receptor; MOR, $\mu$-opioid receptor; OR, opioid receptor; PET, positron emission tomography

\section{REFERENCES}

(1) Dannals, R. F. Positron emission tomography radioligands for the opioid system. J. Labelled Compd. Radiopharm. 2013, 56, 187-195.

(2) Pfeiffer, A.; Pasi, A.; Mehraein, P.; Herz, A. Opiate receptor binding sites in human brain. Brain Res. 1982, 248, 87-96.

(3) Tempel, A.; Zukin, R. S. Neuroanatomical patterns of the $\mu, \delta$ and $\kappa$ opioid receptors of rat brain as determined by quantitative in vitro autoradiography. Proc. Natl. Acad. Sci. U.S.A. 1987, 84, 4308-4312.

(4) Mansour, A.; Khachaturian, H.; Lewis, M. E.; Akil, H.; Watson, S. L. Autoradiographic differentiation of $\mathrm{mu}$, delta and kappa opioid receptors in the rat forebrain and midbrain. J. Neurosci. 1987, 7, 24452464.

(5) Hume, S. P.; Lingford-Hughes, A. R.; Nataf, V.; Hirani, E.; Ahmad, R.; Davies, A. N.; Nutt, D. J. Low sensitivity of the positron emission tomography ligand $\left[{ }^{11} \mathrm{C}\right]$ diprenorphine to agonist opiates. J. Pharmacol. Exp. Ther. 2007, 322, 661-667.

(6) Frost, J. J. PET imaging of the opioid receptor: the early years. Nucl. Med. Biol. 2001, 28, 509-513.

(7) Riss, P. J.; Hong, Y. T.; Marton, J.; Caprioli, D.; Williamson, D. J.; Ferrari, V.; Saigal, N.; Roth, B. L.; Henriksen, G.; Fryer, T. D.; Dalley, J. W.; Aigbirhio, F. I. Synthesis and evaluation of ${ }^{18} \mathrm{~F}-\mathrm{FE}-\mathrm{PEO}$ in rodents: an ${ }^{18} \mathrm{~F}$-labeled full agonist for opioid receptor imaging. J. Nucl. Med. 2013, 54, 299-305.

(8) Quelch, D. R.; Katsouri, L.; Nutt, D. J.; Parker, C. A.; Tyacke, R. J. Imaging endogenous opioid peptide release with $\left[{ }^{11} \mathrm{C}\right]$ carfentanil and $\left[{ }^{3} \mathrm{H}\right]$ diprenorphine: Influence of agonist-induced internalization. $J$. Cereb. Blood Flow Metab. 2014, 34, 1604-1612.

(9) Raehal, K. M.; Schmid, C. L.; Groer, C. E.; Bohn, L. M. Functional selectivity at the $\mu$-opioid receptor: implications for understanding opioid analgesia and tolerance. Pharmacol. Rev. 2011, 63, 1001-1019.

(10) Hume, S. P.; Gunn, R. N.; Jones, T. Pharmacological constraints associated with positron emission tomographic scanning of small laboratory animals. Eur. J. Nucl. Med. 1998, 25, 173-176. 
(11) Keith, D. E.; Anton, B.; Murray, S. R.; Zaki, P. A.; Chu, P. C.; Lissin, D. V.; Monteillet-Agius, G.; Stewart, P. L.; Evans, C. J.; Zastrow, M. v. mu-Opioid receptor internalization: opiate drugs have differential effects on a conserved endocytic mechanism in vitro and in the mammalian brain. Mol. Pharmacol. 1998, 53, 377-384.

(12) Riss, P. J.; Hong, Y. T.; Williamson, D.; Caprioli, D.; Sitnikov, S.; Ferrari, V.; Sawiak, S. J.; Baron, J.-C.; Dalley, J. W.; Fryer, T. D.; Aigbirhio, F. I. Validation and quantification of $\left[{ }^{18} \mathrm{~F}\right]$ altanserin binding in the rat brain using blood input and reference tissue modeling. J. Cereb. Blood Flow Metab. 2011, 31, 2334-2342.

(13) Goldstein, A.; Naidu, A. Multiple opioid receptors: ligand selectivity profiles and binding site signatures. Mol. Pharmacol. 1989, 36, 265-272.

(14) Emmerson, P.J.; Liu, M.R.; Woods, J.H.; Medzihradsky, F. Binding affinity and selectivity of opioids at mu, delta and kappa receptors in monkey brain membranes. J. Pharmacol. Exp. Ther. 1994, 271, 1630-1637.

(15) Rafique, W.; Khanapur, S.; Spilhaug, M. M.; Riss, P. J. Reaching out for sensitive evaluation of the mu opioid receptor in vivo: positron emission tomography imaging of the agonist $\left[{ }^{11} \mathrm{C}\right] \mathrm{AH} 7921$. ACS Chem. Neurosci. 2017, 8, 1847-1852.

(16) Hitchcock, S. A.; Pennington, L. D. Structure-brain exposure relationships. J. Med. Chem. 2006, 49, 7559-7583.

(17) Ertl, P.; Rohde, B.; Selzer, P. Fast calculation of molecular polar surface area as a sum of fragment-based contributions and its application to the prediction of drug transport properties. J. Med. Chem. 2000, 43, 3714-3717. Huang, W.; Manglik, A.; Venkatakrishnan, A. J.; Laeremans, T.; Feinberg, E. N.; Sanborn, A. L.; Kato, H. E.; Livingston, K. E.; Thorsen, T. S.; Kling, R. C.; Granier, S.; Gmeiner, P.; Husbands, S. M.; Traynor, J. R.; Weis, W. I.; Weis, W. I.; Steyaert, J.; Dror, R. O. Structural insights into $\mu$-opioid receptor activation. Nature 2015, 524, 315-321.

(18) Nebel, N.; Strauch, B.; Maschauer, S.; Lasch, R.; Rampp, H.; Fehler, S. K.; Bock, L. R.; Hübner, H.; Gmeiner, P.; Heinrich, M. R.; Prante, O. $\left[{ }^{18} \mathrm{~F}\right]$ Fluorophenylazocarboxylates: design and synthesis of potential radioligands for dopamine D3 and $\mu$-opioid receptor. ACS Omega 2017, 2, 8649-8659.

(19) Hübner, H.; Haubmann, C.; Utz, W.; Gmeiner, P. Conjugated enynes as nonaromatic catechol bioisosteres: synthesis, binding experiments, and computational studies of novel dopamine receptor agonists recognizing preferentially the $\mathrm{D} 3$ subtype. J. Med. Chem. 2000, 43, 756-762.

(20) Pfeiffer, A.; Sadee, W.; Herz, A. Differential regulation of the mu-, delta-, and kappa-opiate receptor subtypes by guanyl nucleotides and metal ions. J. Neurosci. 1982, 2, 912-917.

(21) Saccone, P. A.; Lindsey, A. M.; Koeppe, R. A.; Zelenock, K. A.; Shao, X.; Sherman, P.; Quesada, C. A.; Woods, J. H.; Scott, P. J. H. Intranasal opioid administration in rhesus monkeys: PET imaging and antinociception. J. Pharmacol. Exp. Ther. 2016, 359, 366-373.

(22) Wohlfarth, A.; Scheidweiler, K. B.; Pang, S.; Zhu, M.; Castaneto, M.; Kronstrand, R.; Huestis, M. A. Metabolic characterization of AH7921, a synthetic opioid designer drug: in vitro metabolic stability assessment and metabolite identification, evaluation of in silico prediction, and in vivo confirmation. Drug Test. Anal. 2016, 8, 779791.

(23) Paxinos, G.; Watson, C. The Rat Brain in Stereotaxic Coordinates; Academic Press: San Diego, CA, 1998.

(24) Innis, R. B.; Cunningham, V. J.; Delforge, J.; Fujita, M.; Gjedde, A.; Gunn, R. N.; Holden, J.; Houle, S.; Huang, S.-C.; Ichise, M.; Iida, H.; Ito, H.; Kimura, Y.; Koeppe, R. A.; Knudsen, G. M.; Knuuti, J.; Lammertsma, A. A.; Laruelle, M.; Logan, J.; Maguire, R. P.; Mintun, M. A.; Morris, E. D.; Parsey, R.; Price, J. C.; Slifstein, M.; Sossi, V.; Suhara, T.; Votaw, J. R.; Wong, D. F.; Carson, R. E. Consensus nomenclature for in vivo imaging of reversibly binding radioligands. J. Cereb. Blood Flow Metab. 2007, 27, 1533-1539.

(25) Virdee, K.; Cumming, P.; Caprioli, D.; Jupp, B.; Rominger, A.; Aigbirhio, F. I.; Fryer, T. D.; Riss, P. J.; Dalley, J. W. Applications of positron emission tomography in animal models of neurological and neuropsychiatric disorders. Neurosci. Biobehav. Rev. 2012, 36, 11881216.

(26) Männel, B.; Dengler, D.; Shonberg, J.; Hübner, H.; Möller, D.; Gmeiner, P. Hydroxy-substituted heteroarylpiperazines: novel scaffolds for $\beta$-arrestin-biased $\mathrm{D}_{2} \mathrm{R}$ agonists. J. Med. Chem. 2017, 60, 4693-4713.

(27) Rafique, W.; Kramer, V.; Pardo, T.; Smits, R.; Spilhaug, M. M.; Hoepping, A.; Savio, E.; Engler, H.; Kuljs, R.; Amaral, H.; Riss, P. J. Image-guided development of heterocyclic sulfoxides as ligands for tau neurofibrillary tangles: from first-in-man to second-generation ligands. ACS Omega 2018, 3, 7567-7579.

(28) Ott, J. J. Selective Neuropeptide and Opioid Receptor Radioligands for Imaging Studies in Vivo by Positron Emission Tomography (PET). Ph.D. Thesis, Friedrich-Alexander-Universität Erlangen-Nürnberg (FAU), 2018, urn:nbn:de:bvb:29-opus4-99474. 